\title{
Article \\ Construction of the Primorsky No. 1 and No. 2 International Transport Corridors: Risk Evaluation and Mitigation Policies
}

\author{
Yang Yang ${ }^{1}$, Suocheng Dong ${ }^{1,2}$, Tamir Boldanov ${ }^{1,2}$, Fujia Li 1,2,3,*, Hao Cheng ${ }^{1}$, Qian Liu ${ }^{1,2}$, Yu Li 1,2 ${ }^{1 D}$ and \\ Zehong Li ${ }^{1,2}$
}

check for updates

Citation: Yang, Y.; Dong, S.; Boldanov, T.; Li, F.; Cheng, H.; Liu, Q.; Li, Y.; Li, Z. Construction of the Primorsky No. 1 and No. 2 International Transport Corridors: Risk Evaluation and Mitigation Policies. Sustainability 2021, 13, 2120. https: / doi.org/10.3390/su13042120

Received: 31 December 2020

Accepted: 10 February 2021

Published: 16 February 2021

Publisher's Note: MDPI stays neutral with regard to jurisdictional claims in published maps and institutional affiliations.

Copyright: (c) 2021 by the authors. Licensee MDPI, Basel, Switzerland. This article is an open access article distributed under the terms and conditions of the Creative Commons Attribution (CC BY) license (https:/ / creativecommons.org/licenses/by/ $4.0 /)$.
1 Department of Resources Economics and Mineral Resources Research, Institute of Geographic Sciences and Natural Resources Research, CAS, Beijing 100101, China; yangy.15b@igsnrr.ac.cn (Y.Y.); dongsc@igsnrr.ac.cn (S.D.); tboldanov2018@igsnrr.ac.cn (T.B.); chenghao@igsnrr.ac.cn (H.C.); liuqian.18s@igsnrr.ac.cn (Q.L.); liy@igsnrr.ac.cn (Y.L.); lizehong@igsnrr.ac.cn (Z.L.)

2 College of Resource and Environment, University of Chinese Academy of Sciences, Beijing 100049, China

3 Innovation Academy for Green Manufacture, CAS, Beijing 100190, China

* Correspondence: lifj@igsnrr.ac.cn

\begin{abstract}
The construction of the Primorsky No. 1 and No. 2 international transport corridors is of great strategic significance to China and Russia. These corridors will solve the problem of the absence of an estuary in Northeast China by sailing from Russian ports and concurrently greatly improve Russia's position in the world's transport system. However, existing research studies mainly focus on the strategic significance of these corridors, while research studies on the identification, evaluation, and mitigation policies of their construction risks are rare, which inhibits the construction progress. To promote the construction of these corridors, we firstly identify the main risks in the construction of these corridors, which are economic, transport infrastructure-related, policy-related, eco-environmental, and disaster-related risks. Then, we establish a comprehensive evaluation system, and by applying the entropy method, we quantitatively evaluate the degrees of risks in regions along the transport corridors, reveal their spatial distribution patterns, and identify the key prevention and control regions for these risks. Afterwards, we propose targeted mitigation policies such as establishing innovative cooperation modes and a special foundation to mitigate economic risk and formulate further regional development policies to mitigate policy-related risk. This research will provide scientific support for risk prevention and control for the construction of these corridors.
\end{abstract}

Keywords: Primorsky No. 1 and No. 2 international transport corridors; risk evaluation; spatial distribution; mitigation policies; entropy method

\section{Introduction}

In July 2017, China and Russia signed the "Memorandum of Understanding on the Joint Development of the Primorsky No. 1 and No. 2 International Transport Corridors." The two parties pledged to jointly construct the transport corridors that connect the Chinese provinces of Heilongjiang and Jilin with ports in Primorsky and to modernize the infrastructure of the ports, highways, and railways in the regions along the corridors. According to the memorandum, in 2030, the two corridors will annually transport 45 million tons of cargo, which will lead to an increase of 1.49 billion USD in the annual revenues of the ports and land transport companies compared to that in 2015 [1,2]. The Primorsky No. 1 and No. 2 international transport corridors are the first land transport corridors under construction as part of the China-Mongolia-Russia Economic Corridor. Their construction and operation will solve the problem of the absence of an estuary in Northeast China and facilitate exports from Russia's seaports [3-5]. At the same time, through the consequent development of the seaports, logistics, and transport industry in Primorsky, the area will become a strategically important channel connecting Northeast Asia and Europe, reshape the global transport system, and enhance Russia's position in Northeast Asia and 
the world [6-8]. Additionally, by developing the transport, logistics, and warehousing industry, it will promote the development of tourism, accommodation, and other related industries, which will greatly promote the sustainable development of economy in regions along these corridors.

However, the construction of these transport corridors is costly, will take a long time, and is fraught with various difficulties and risks. This construction will be directly affected by the local economic, policy-related, eco-environmental, and geological conditions [9-11]. Moreover, the Primorsky No. 1 and No. 2 international transport corridors include multiple cross-border regions and ecological systems. The Russian regions along the corridors are far from the country's national administrative center and have been marginalized for a long time, resulting in poor economic development, a sparse population, and few policy benefits in these regions. Meanwhile, the Russian regions are adjacent to the Sea of Japan (East Sea), so natural disasters such as floods and tsunamis occur frequently. Therefore, to promote the construction of the Primorsky No.1 and No.2 international transport corridors, it is important to clarify the main risk-related factors affecting the construction of these two corridors, quantitatively evaluate the degrees of these risks, reveal the patterns of their spatial distribution, and formulate targeted mitigation policies to prevent and control these risks.

At present, research has been mainly devoted into the strategic significance, opportunities, and challenges of Sino-Russia transport corridors. Baklanov of the Russian Academy of Sciences explicitly stated the strategic demands for constructing the Sino-Russia international transport corridor in "Geosystems of Far East of Russia on Boundary of XX-XXI Century" in 2008 [12] and "Pacific Russia: Pages of Past, Present, and Future" in 2012 [13]. Russian scholar Sazonov studied ways to enhance Russia's participation in the Asia-Pacific region and Europe by promoting its integration into the international transport system and made suggestions regarding the construction of a transport system in the Far East $[6,14]$. Aristova et al. analyzed the opportunities and challenges of the construction of a SinoRussia transport system under the "the Belt and Road Initiative" and stated that this was not only an opportunity to promote mutual cooperation but also to overcome the sanctions blockading the Russian financial sector by Western countries [8]. Chinese scholars Liang and Chen studied the problem of the poor infrastructure of the Sino-Russia international channel and noted that coordinated domestic and international relations and the development of a cross-border economic zone can help improve this infrastructure [3]. Korean scholar Sub (2019) analyzed the economic effects of the construction of the Primorsky No.1 and No.2 international transport corridors in detail and noted that they were important transportation hubs for connecting Northeast Asia [15]. Additionally, Ding et al. [16], Guo et al. [17], Liu et al. [18], and Li [19] all studied the strategic significance of the construction of a Sino-Russian cross-border transport corridor.

Prevalent research has focused on theoretical explorations of the construction of the Sino-Russian international transport corridor, without including identification of the main risk factors, a quantitative evaluation of the degrees of risk, an analysis of the mechanism of the risk impacts, and targeting mitigation policies to prevent and control these risks. Thus, research in the area cannot currently meet the urgent needs of the construction of the Primorsky No. 1 and No. 2 international transport corridors.

Aiming at the above deficiencies, in this study, we firstly identify the main risk-related factors in the construction of the Primorsky No. 1 and No. 2 international transport corridors. Then, we establish a comprehensive risk evaluation system to quantitatively evaluate the degrees of risks, revealing their mechanisms of impact and patterns of spatial distribution. Afterwards, we propose targeted mitigation policies to prevent and control these risks. The work here will provide scientific support for risk prevention and control for the construction of the Primorsky No. 1 and No. 2 international transport corridors and promote their construction progress. 


\section{Materials and Methods}

\subsection{Research Area}

According to the "Sino Russian Cooperative Development Plan in the Far East of Russia (2018-2024)" [20], the route of the Primorsky No. 1 international transport corridor is the Harbin-Mudanjiang-Suifenhe-Pogranichnyy-Ussuriyskiy-Vladivostok port/Vostochnyy port/Nakhodka port (Figure 1). The route of the Primorsky No. 2 international transport corridor is the Changchun-Jilin-Hunchun-Zarubino port. Among the included regions, high-speed railways, expressways, and normal-speed railways for the Harbin-MudanjiangSuifenhe and Changchun-Jilin-Hunchun routes have been completed and are in operation. The regional transport infrastructure is mature, and the transport capacity is large. However, the transport infrastructure of the Russian regions along the routes is weak, the road network density is low, and most railways are traditional railways with a relatively small transport capacity such that they cannot meet the transport demands of large commodities. Therefore, improving the transport infrastructure in the Russian regions along the corridor is the core aim of the construction of the Primorsky No. 1 and No. 2 international transport corridors. Thus, the research area of this paper consists of Russian regions along the two routes, including Pogranichnyy, Oktyabr, Ussuriyskiy, Nadezhdinskiy, Artem, Vladivostok, Shkotovskiy, Nakhodka, and Khasanskiy.

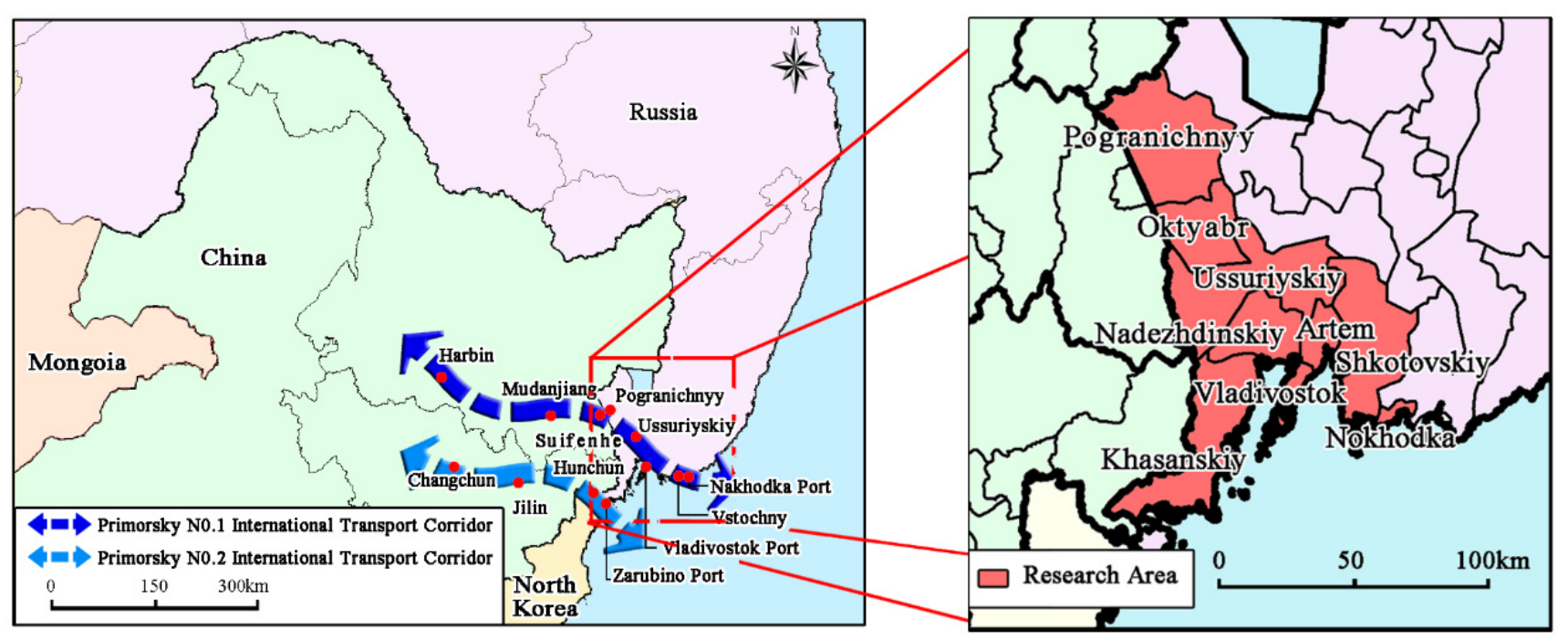

Figure 1. Map of the research area.

\subsection{Risk-Related Factors in Constructing Transport Corridors}

The construction of the international transport corridor is a complex engineering task that requires a massive financial investment and involves a long return cycle for that investment, along with many industrial sectors, complex engineering problems, stringent requirements, and a significant impact on the regional economic, social, and ecological conditions [9-11,21-24]. Therefore, during the construction and operation of the transport corridors, the relevant risk factors must be fully considered, and targeted mitigation policies to prevent and control risks must be formulated.

At present, there are a few studies on the risk evaluation of construction for transport corridors, railways, and highways. The main risk factors can mainly be summarized as the following five aspects: economic factors, transport infrastructure-related factors, policy-related factors, eco-environmental factors, and disaster-related factors. For instance, Dong et al. studied the risk factors for constructing the China-Mongolia-Russia highspeed railway and noted economic development, transport infrastructure, government and residential support, social stability, ecology, and disasters as the main risk factors [10]. Dong et al. studied the international transport network and indicated that the massive costs, the 
environment, and technology were the main restraining factors for constructing transport corridors [25]. Yang et al. and Jin et al. concluded that economic risk (risk brought about the social economic situation of the target region), population risk (average quality of people's life of the target region), traffic risk (the current national overall traffic level of the target region), and political risk (the current domestic policies and regulations of the target region) were the main risks that need to be considered for railway construction [26,27]. Liu et al. established an evaluation index system for investment risk of highway construction, in which political risk, economic risk, environment risk, management risk, and technological risk were listed as five risks [28]. Benítez-López et al. and Beyer et al. studied the risk of the construction of roads to mammal [29,30], while Kociolek studied that for birds [31], and they concluded that roads were a substantial threat to biodiversity. The factor of biodiversity must be seriously considered when constructing roads. Wang determined that eco-environmental destruction was one of the main risks for constructing the ChinaMongolia-Russia Economic Corridor [32].

Meanwhile, our team has studied transport construction, regional economic development, and the ecological environment in the Russian Far East since 2005, conducted more than 10 field investigations in the research area, and accumulated large amounts of statistical and sampling data and research experiences [33,34]. Additionally, we have recruited four Russian Ph.D. students in our team to collaboratively conduct research on Sino-Russian cooperation. In this way, we have obtained substantial data and a relatively clear knowledge of the economic development, transport factors, regional policies, ecoenvironment, and geology of the research area, which will help us identify the main risk factors for constructing the Primorsky No. 1 and No. 2 transport corridors.

Thus, by comprehensively reviewing the existing studies, analyzing current economic, transport, regional policies, the eco-environment, and the geological status of the research area alongside our team's long-term research experience, risk factors in the construction of the Primorsky No. 1 and No. 2 international transport corridors were determined to be based on the following five aspects.

(1) Economic risk. The cost for the construction of the Primorsky No. 1 and No. 2 international transport corridors is massive. The average cost of the construction of a road and railway in Russia is 320,000 USD/ $\mathrm{km}$ and 360,000 USD/km, respectively [35,36]. According to the "Development concept of Primorsky No.1 and Primorsky No.2 international transport corridor", the total length of the roads that need to be constructed or upgraded is $537.65 \mathrm{~km}$ [37], while that for the railways is estimated to be $380 \mathrm{~km}$, which will cost 309 million USD or more due to the extremely cold weather in the Far East. Therefore, the level of economic development of the regions along the transport corridor will directly affect the feasibility of the construction of the corridors. However, most of the regions in the research area (hereafter called research regions) are economically backward and sparsely populated. In 2017, the GDP per capita and the total population of Vladivostok, which is the most developed region in the research area, was 888 USD and 633,000, respectively. Thus, these regions may not have sufficient construction funds, which enhances the economic risk.

(2) Transport infrastructure-related risk. The transport infrastructure of the research area is poor. Road densities in the research regions (expect for Vladivostok) are all lower than $2 \mathrm{~km} / \mathrm{km}^{2}$ [38], and the road that needs to be constructed and upgraded is long (as mentioned in (1) Economic risk). Meanwhile, most railways in the research area are traditional railways with a slow speed and small capacity, which also demands large-scale construction, upgrading, and modernization, thus greatly increasing the construction costs and difficulty for the transport corridors.

(3) Policy-related risk. Policy incentives are important for the construction of transport infrastructure [26-28]. Preferential policies often come along with supporting measures such as tax deductions and exemptions, which can bring in capital, projects, and other factors, and they can significantly promote regional economic development and the construction of transport infrastructure. Therefore, whether the central and 
local governments have issued specific regional developmental policies and special transport construction policies in Primorsky is crucial for the construction of the Primorsky No. 1 and No. 2 international transport corridors. The greater the policy support provided, the smaller the policy-related risk will be, and vice versa. Although Russia has strengthened its policy support for Primorsky, due to differences in the locational characteristics and levels of economic development in the research regions, the degree of policy support varies greatly. Regions with low policy support may not have enough policy incentives and capacity to construct the transport corridors. This increases policy-related risks.

(4) Eco-environmental risk. The research area has a good ecological environment and rich biodiversity. The forest coverage of the eight research regions is greater than 60\% [39]. The Leopard National Park, Far East Marine Reserve, Ussuriyskiy Natural Reserve, and a large number of rare animals and plants, such as the Far East leopard, Siberian tiger, Himalayan bear, ginseng, and rock cabbage, are distributed in the research area. However, the construction of the Primorsky No. 1 and No. 2 international transport corridors may disturb or damage the ecological environment in the construction zone, thus destroying the related ecosystems and endangering biodiversity [40-42]. Therefore, it is important to quantitatively examine the degrees of eco-environmental risk in the research regions and propose targeted mitigation policies to prevent and control that risk.

(5) Disaster-related risk. The disaster-related conditions in the research area directly affect the feasibility and difficulty of transport-related construction. The research area is adjacent to the Sea of Japan (East Sea), where floods, tsunamis, landslides, and other natural and geological disasters occur frequently. Disaster-related factors are direct risk-related factors for the construction of the Primorsky No. 1 and No. 2 international transport corridors and must be avoided. Therefore, it is important to quantitatively examine the degrees of disaster-related risk in the research regions and formulate targeted prevention and control countermeasures.

\subsection{Comprehensive Risk Evaluation System}

To build the comprehensive evaluation system for economic, transport infrastructurerelated, policy-related, eco-environmental, and disaster-related risks for the Primorsky No. 1 and No. 2 international transport corridors, we first reviewed the related evaluation indices adopted in previous studies, as shown in Tables 1 and 2. Then, based on the principles of the accessibility, typicality, and comparability of the data selection, we established the comprehensive evaluation system, as shown in Table 3.

(1) Indices of economic risk. To evaluate the economic risk in the research regions, ten indices, including the income of municipal budgets, the average monthly income from work, investments in fixed capital, the proportion of agriculture, the proportion of industry, and the proportion of tertiary industry, were selected to reflect the economic development of the research regions. A better economic development level implies a stronger investment ability for constructing the transport corridors and thus a smaller economic risk. A total number of 14 indices, including natural resources such as healing mud, gold, brown coal, and Ge, and human resources such as total population, natural increases in population, and percentage of the working, were selected to reflect resource endowment. Richer resource endowment implies higher regional attractive power and thus smaller economic risk. Nine indices, including the percentage of unemployed persons registered in the state employment service, the number of doctors per 10,000 people, and the number of sports facilities per 10,000 people, were selected to reflect living standards. Better living standards also indicate higher regional attractive power and smaller economic risk. Therefore, the better the level of economic development, the richer the resource endowment and the better the living standard, and the lower the economic risk is to the construction of the Primorsky No. 1 and No. 2 international transport corridors. 
(2) Indices of transport infrastructure-related risk. Indices to reflect road network, including the length of all roads (for cars) and density of roads, and indices to reflect transported freight, including amount of transported goods, the annual increase of transported goods in 2017, and annual increase of cargo turnover in 2017, were selected to evaluate the transport infrastructure-related risk for the two transport corridors. Poor transport infrastructure results in higher costs for exploring and evaluating the local geology, geomorphology, and the natural environment for construction of the corridors, and it enhances the construction costs and difficulty of the corridors.

(3) Indices of policy-related risk. We collected and analyzed 10 closely related regional development policies and plans, as well as special transport construction policies and plans issued by the Russian government at all levels, along with those co-issued by China and Russia. Then, we analyzed if a research region is included in a policy or plan because inclusion in a policy usually implies policy support and is important for constructing the corridors. The stronger the policy support, the lower the policyrelated risk will be.

(4) Indices of eco-environmental risk. Ten ecology indices, including the percentage of agriculture land, percentage of forest, percentage of grassland, the precipitation, and the number of natural reserves and nine environment pollution indices, such as the emissions of pollutants into the atmosphere in cities and districts, discharges of solids, and emissions of gases and liquids, were selected to evaluate the eco-environmental risk. A better eco-environmental condition implies a potentially greater risk of ecoenvironmental damage.

(5) Indices of disaster-related risk. Six natural disasters that occur frequently in the research area were selected to evaluate the disaster-related risk in the research regions. The higher the grade of a disaster, the higher the disaster-related risk, and the greater the restrictions on the construction of the transport corridors will be.

Table 1. Economic-related indices adopted in previous research.

\begin{tabular}{|c|c|}
\hline Indices & Authors (Years) \\
\hline $\begin{array}{l}\text { GDP, GDP per capita, growth rate of GDP, population density, growth rate of } \\
\text { population, tourism resources, energy resources, mineral resources, educational } \\
\text { resources; }\end{array}$ & Dong et al. (2018) [10] \\
\hline $\begin{array}{l}\text { Income, investment in fixed assets, foreign direct investment, industrial } \\
\text { structure, total population, population density, natural population growth rate, } \\
\text { unemployment rate, amount of beds per } 10,000 \text { persons in hospital, amount of } \\
\text { doctors for 10,000 people, amount of scientific researchers, land resources, forest } \\
\text { resources, coal resources; }\end{array}$ & Li et al. (2019) [43] \\
\hline $\begin{array}{l}\text { GDP per capita, population density, percentage of urban population, number of } \\
\text { vehicles per 10,000 people, number of general education schools; }\end{array}$ & Dong et al. (2019) [44] \\
\hline $\begin{array}{l}\text { GDP, GDP per capita, annual growth rate of GDP, census register population, } \\
\text { natural population growth rate, registered unemployment rate in cities and } \\
\text { towns, forest coverage rate, coverage rate of green area in completed } \\
\text { construction area, public green space per capita; }\end{array}$ & Shi et al. (2016) [45] \\
\hline $\begin{array}{l}\text { GDP per capita, total fixed assets investment per capita, industrial stucture, } \\
\text { growth rate of GDP, population density, population growth rate, urbanization } \\
\text { rate, disposable income of urban residents per capita, living area per capita in } \\
\text { urban, registered urban unemployment rate, number of hospital beds per } \\
\text { thousand persons, forest coverage rate; }\end{array}$ & Shi et al. (2019) [46] \\
\hline $\begin{array}{l}\text { Amount of foreign direct investment, annual GDP growth rate, population } \\
\text { growth rate, the number of health technicians per } 1000 \text { permanent residents, the } \\
\text { number of institutional beds for every } 1000 \text { elderly people, higher education } \\
\text { enrollment rate, water consumption per } 10,000 \text { USD of GDP, standard coal } \\
\text { consumption per 10,000 USD of GDP }\end{array}$ & Lin et al. (2020) [47] \\
\hline
\end{tabular}


Table 2. Transport infrastructure-related, policy-related, eco-environmental, and disaster-related indices adopted in previous studies.

\begin{tabular}{|c|c|c|}
\hline Indices & Detailed Indices & Authors (Years) \\
\hline \multirow{3}{*}{$\begin{array}{l}\text { Transport } \\
\text { infrastructure-related } \\
\text { indices }\end{array}$} & Railway network density; & Dong et al. (2018) [10] \\
\hline & $\begin{array}{l}\text { Railway density, highway density, freight, freight turnover, passenger capacity, } \\
\text { passenger turnover; }\end{array}$ & Li et al. (2019) [43] \\
\hline & Number of urban public transport vehicles for every million persons; & Shi et al. (2019) [46] \\
\hline \multirow[b]{2}{*}{ Policy-related indices } & government and residential support & Dong et al. (2018) [10] \\
\hline & $\begin{array}{c}16 \text { related policies and plans were analyzed to reflect policy support in } \\
\text { research regions }\end{array}$ & Li et al. (2019) [43] \\
\hline \multirow{5}{*}{$\begin{array}{l}\text { Eco-environmental } \\
\quad \text { indices }\end{array}$} & Forest coverage rate, number of natural reserves, biodiversity; & Dong et al. (2018) [10] \\
\hline & $\begin{array}{l}\text { Nitrogen dioxide content in air, industrial soot emissions, emission reduction } \\
\text { of main pollutants } \mathrm{SO}_{2} \text {, urban wastewater discharge; }\end{array}$ & Shi et al. (2016) [45] \\
\hline & $\begin{array}{l}\text { Annual precipitation, number of rivers, number of lakes, sown areas per } \\
\text { capita, forest harvest volume per capita; }\end{array}$ & Dong et al. (2019) [44] \\
\hline & $\begin{array}{l}\text { Ammonia-nitrogen emissions per unit GDP, COD emissions per unit GDP, } \\
\mathrm{SO}_{2} \text { emissions per unit GDP, NOx emissions per unit GDP, soot emissions per } \\
\text { unit GDP, industrial solid waste emissions per unit GDP, area of public park } \\
\text { per capita, coverage rate of green area in built-up areas, proportion of natural } \\
\text { reserve area to total land area; }\end{array}$ & Shi et al. (2019) [46] \\
\hline & $\begin{array}{l}\text { Water surface rate, proportion of hazardous waste treatment, proportion of } \\
\text { non-fossil energy consumption to primary energy consumption, the } \\
\text { proportion of days when PM2.5 reached the standard in towns, and the annual } \\
\text { decline rate of greenhouse gas emissions; }\end{array}$ & Lin et al. (2020) [47] \\
\hline $\begin{array}{l}\text { Disaster-related } \\
\text { indices }\end{array}$ & Area of forest fire, number of geologic hazards. & Dong et al. (2018) [10] \\
\hline
\end{tabular}

Table 3. Comprehensive evaluation system of economic, transport infrastructure-related, policy-related, eco-environmental, and disaster-related risks of Primorsky No. 1 and No. 2 international transport corridors.

\begin{tabular}{|c|c|c|}
\hline $\begin{array}{l}\text { First-Level } \\
\text { Indices }\end{array}$ & $\begin{array}{l}\text { Second-Level } \\
\text { Indices }\end{array}$ & Third-Level Indices (Unit) \\
\hline \multirow{3}{*}{ Economic risk } & $\begin{array}{c}\text { Economic } \\
\text { development }\end{array}$ & 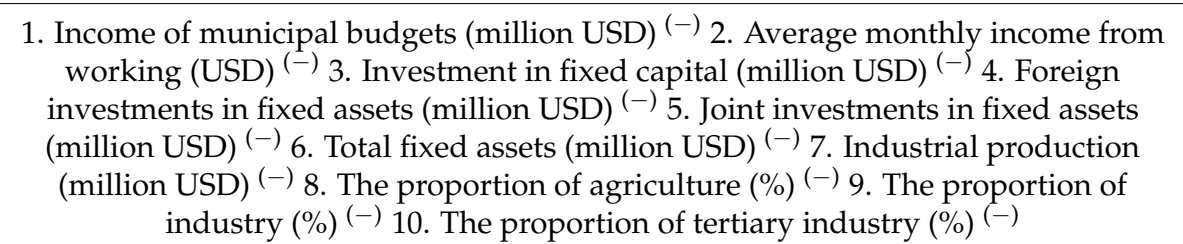 \\
\hline & $\begin{array}{c}\text { Resource } \\
\text { endowment }\end{array}$ & 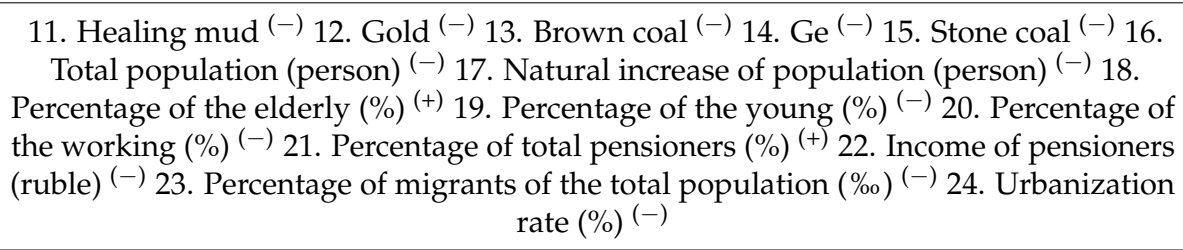 \\
\hline & Living standard ${ }^{(-)}$ & $\begin{array}{l}\text { 25. Percentage of unemployed persons registered in the state employment service }(\%) \\
\left(^{+)} \text {26. Average number of employees }(\%)^{(-)} 27 \text {. Number of crimes per } 10,000 \text { people }\right. \\
\text { (person) }{ }^{(+)} 28 \text {. Number of beds per } 10,000 \text { people (person) }{ }^{(-)} 29 \text {. Number of people } \\
\text { per bed (person) }{ }^{(+)} 30 \text {. Number of doctors per } 10,000 \text { people (person) }{ }^{(-)} 31 \text {. Number } \\
\text { of sports facilities per } 10,000 \text { people (number) }{ }^{(-)} 32 \text {. Number of hotels per } 10,000 \\
\text { people (number) }\end{array}$ \\
\hline \multirow{2}{*}{$\begin{array}{l}\text { Transport } \\
\text { infrastructure- } \\
\text { related } \\
\text { risk }\end{array}$} & Road network ${ }^{(-)}$ & 34. Length of all roads (for cars) $(\mathrm{km})^{(-)} ; 35$. Density of roads $\left(\mathrm{km} / \mathrm{km}^{2}\right)^{(-)}$ \\
\hline & Transported freight ${ }^{(-)}$ & $\begin{array}{l}\text { 36. Amount of transported goods (thousand tons) }{ }^{(-)} \text {37. Annual increase of } \\
\text { transported goods in } 2017(\%)^{(-)} 38 \text {. Annual increase of cargo turnover in } 2017(\%)^{(-)}\end{array}$ \\
\hline
\end{tabular}


Table 3. Cont.

\begin{tabular}{|c|c|c|}
\hline $\begin{array}{l}\text { First-Level } \\
\text { Indices }\end{array}$ & $\begin{array}{l}\text { Second-Level } \\
\text { Indices }\end{array}$ & Third-Level Indices (Unit) \\
\hline $\begin{array}{l}\text { Policy-related } \\
\text { risk }\end{array}$ & Policies and plans ${ }^{(-)}$ & $\begin{array}{l}\text { 39. Sino-Russian Cooperative Development Plan in the Far East of Russia (2018-2024) } \\
(-) \text { 40. Memorandum of Understanding on the Joint Development of the Primorsky } \\
\text { No. } 1 \text { and No. } 2 \text { International Transport Corridors }{ }^{(-)} 41 \text {. Free Distribution Act of } \\
\text { Russian Far East Land }{ }^{(-)} 42 \text {. Socio-Economic Development Strategy of Russian Far } \\
\text { East } 43 \text {. National Planning of the Russian Federation for Social and Economic } \\
\text { Development in the Far East and Baikal Region }{ }^{(-)} 44 \text {. Outline for the Development of } \\
\text { Russia's Far East Border Region from } 2015 \text { to } 2025^{(-)} 45 \text {. Vladivostok Agglomeration } \\
\text { Development Project }{ }^{(-)} 46 . \text { Nakhodka Transport Hub }{ }^{(-)} 47 \text {. Russia's Advanced } \\
\text { Socio-Economic Development Zone }{ }^{(-)} 48 \text {. East Economic Forum }{ }^{(-)}\end{array}$ \\
\hline \multirow{2}{*}{$\begin{array}{l}\text { Eco- } \\
\text { environmental } \\
\text { risk }\end{array}$} & Ecology ${ }^{(-)}$ & $\begin{array}{l}\text { 49. Percentage of agriculture land }(\%)^{(-)} 50 \text {. Percentage of forest }(\%){ }^{(-)} 51 . \\
\text { Percentage of grassland }(\%){ }^{(-)} 52 \text {. Percentage of wetland }(\%){ }^{(-)} 53 \text {. Precipitation } \\
\left.(\mathrm{mm})^{(-)} 54 \text {. Flow of surface water (liter/ second } / \mathrm{km}^{2}\right)^{(-)} 55 . \text { Number of natural } \\
\text { reserves }{ }^{(-)} 56 . \text { Number of national parks }{ }^{(-)} 57 \text {. Number of species of rare animals } \\
\left(_{(-)} 58 . \text { Number of species of rare plants }\right.\end{array}$ \\
\hline & $\begin{array}{l}\text { Emissions of } \\
\text { pollutants }\end{array}$ & 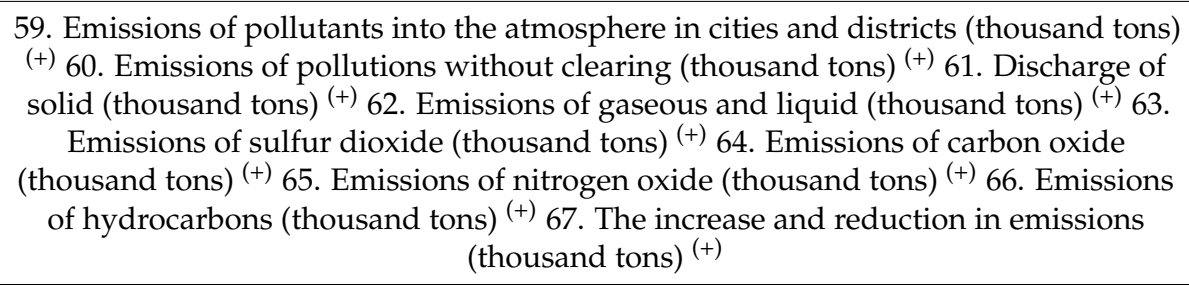 \\
\hline $\begin{array}{c}\text { Disaster-related } \\
\text { risk }\end{array}$ & Grades of disasters $^{(+)}$ & 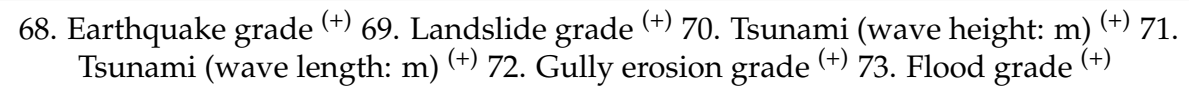 \\
\hline
\end{tabular}

Note: ${ }^{(+)}$represents the index belongs to type A index, ${ }^{(-)}$represents the index belongs to type B index. Units of the indices are listed in brackets right after the indices. The definition of the unit of policy-related indices is presented in Section 2.4.

The indices in the evaluation system can be further divided into two types: the type A index and the type $\mathrm{B}$ index. For the type $\mathrm{A}$ index, a larger value of the index corresponds to a larger risk - namely, the larger the value, the larger the risk. For a type B index, a larger value corresponds to a smaller risk-namely, the larger the value, the smaller the risk. The type of each index is marked in Table 3.

\subsection{Data Sources}

(1) Data on economic, transport infrastructure-related, eco-environmental, and disasterrelated risk

The data on economic, transport infrastructure-related indices, the emissions of environmental pollutants, precipitation, and flow of surface water were obtained from the "Primorsky Statistical Yearbook 2018" [38].

The data on number of natural reserves/national parks/species of rare animals/species of rare plants, the types and grades of disasters were obtained from the "Atlas of Primorsky Kray" [48] and "Ecological Atlas of Russia" [49], which were co-published by Primorsky Geodetic and Cartographic Information Analysis, Pacific Institute of Geography, Far East Branch of Russian Academy of Sciences, and other organizations.

The data on the percentages of agricultural, forest, grassland, and wetland were obtained by interpreting the map of European Space Agency (ESA): Landcover Climate Change Initiative (CCI) [39]. The ESA:CCI map, which is at $300 \mathrm{~m}$ spatial resolution, divides the landcover into 6 main categories, including agriculture, forest, grassland, wetland, settlement, and other. By overlaying the vector map of prefecture level city in Primorsky, we firstly calculated the area of each category in each research object; then, we calculated 
the proportions of agriculture, forest, grassland, and wetland in the total area of each research object (Formula (1)). All data are from the year 2017.

$$
R_{i}=100 \times \frac{s q r_{i}}{\sum_{i=1}^{6} s q r_{i}}
$$

\section{(2) Data on policy}

Since there are non-spatial quantitative data for policies, by referring to the research conducted by Li, et al. in 2019 [43], we analyzed ten regional development policies, plans, and special transport construction policies and plans that are closely related to the research area, issued by Russian governments at all levels, as well as those co-issued by China and Russia. If a research region is included in a policy or plan, one point is added to its policy score, as shown in Formulae (2) and (3), where $P_{i}$ denotes the policy score of research region $i$.

$$
\begin{gathered}
P_{i r}=\left\{\begin{array}{r}
1 \quad \text { sample } i \text { is included in policy } r \\
0 \quad \text { sample } i \text { is not included in policy } r
\end{array}\right. \\
P_{i}=\sum_{r=1}^{10} P_{i r}
\end{gathered}
$$

\subsection{Methods}

At present, the most widely used methods for comprehensive evaluation and determining the weights of indices can be divided into two categories. One includes the subjective methods, such as Expert Scoring and Delphi. Subjective methods are fully based on the experts' knowledge, experience, and preferences; they are widely used in strategic decisions for objects/systems that are impossible or difficult to quantify. The other includes the objective methods, such as the entropy method, Analytic Hierarchy Process (AHP), and principal component analysis. The objective methods use basic information such as data or language to comprehensively analyze and process the evaluated objects and obtain the evaluation results and are widely used in comprehensive evaluations [50-52]. Since this research is based on data, objective methods are more appropriate. Among the various objective methods, the method of entropy uses the concept of entropy to determine the weight of each subsystem and its constituent elements. The greater the degree of data dispersion, the smaller the information entropy, the greater the impact of the index on the comprehensive evaluation, and the greater the weight will be. The method of entropy can overcome the problems of randomness and conjecture that cannot be avoided by subjective methods and can effectively solve the problem of information overlapping among multiple indices, which is widely used in comprehensive evaluation systems [53,54], especially in systems that contain a large number of indices $[43,55,56]$. Therefore, to objectively and scientifically evaluate risk degree from the construction of the Primorsky No. 1 and No. 2 international transport corridors, we applied the method of entropy to assess the construction risk.

The detailed process of the entropy method is as follows:

Step 1: Normalizing the indices (as shown in Formula (4)). Since the dimensions of the indices are different, normalization of indices is required before making comprehensive evaluation. Here, $x_{i j}$ denotes the value of index $j$ of sample $i, x_{j \max }$ and $x_{j \min }$ denote the maximum and minimum values of index $j$, respectively, and $x_{i j}^{i}$ denotes the normalized value, where $0 \leq x_{i j}^{\prime} \leq 1$. For the type $\mathrm{A}$ index (a larger value of the index corresponds to a larger risk), the bigger the original value $\left(x_{i j}\right)$, the closer the normalized value $\left(x_{i j}^{\prime}\right)$ is to 1 . For the type B index (a larger value of the index corresponds to a smaller risk), the bigger 
the original value, the closer the normalized value is to 0 . By normalization, the values of all indices are converted to values between 0 and 1 (both 0 and 1 included).

$$
\begin{aligned}
& \text { For type A index, } x_{i j}^{\prime}=\frac{x_{i j}-x_{\text {min }}}{x_{\max }-x_{\min }} ; \\
& \text { For type B index, } x_{i j}^{\prime}=\frac{x_{i j}-x_{j \max }}{x_{\min }-x_{\max }} .
\end{aligned}
$$

Step 2: Calculating the proportion of $x_{i j}^{\prime}$ in all normalized values of index $j$ (Formula (5)), namely, the proportion of sample $i$ in all samples of index $j . s_{i j}$ denotes the proportion of $x_{i j}^{\prime}$ in all normalized values of index $j$, and $m$ denotes the number of the samples.

$$
s_{i j}=\frac{x_{i j}^{\prime}}{\sum_{i=1}^{m} x_{i j}^{\prime}}
$$

Step 3: Calculating the entropy of index $\mathrm{j}$ (Formula (6)). Entropy is used to evaluate the degree of data dispersion. The greater the data dispersion, the smaller the information entropy, and the greater the impact of the index on the comprehensive evaluation will be. $e^{j}$ denotes the entropy of index $j, k=\frac{1}{\ln m}, 0<e^{j}<1$. The bigger the $e^{j}$ value, the smaller the impact of index $j$ is on the whole comprehensive evaluation system.

$$
e^{j}=-k \sum_{i=1}^{m} s_{i j} \ln s_{i j}
$$

Step 4: Calculating the redundancy in entropy (Formula (7)). $d_{j}$ denotes the redundancy of index $j$. The bigger the $d_{j}$ value, the more important index $j$ is.

$$
d_{j}=1-e_{j}
$$

Step 5: Calculating the weight of index $\mathrm{j}$ (Formula (8)). $\omega_{j}$ denotes the weight of index $j$ and $n$ denotes the number of indices. $0<\omega_{j}<1, \sum_{j=1}^{n} \omega_{j}=1$. The bigger the $\omega_{j}$ value, the more important index $j$ is.

$$
\omega_{j}=\frac{d_{j}}{\sum_{j=1}^{n} d_{j}}
$$

Step 6: Comprehensively evaluating the value of sample $i$ (Formula (9)). $c_{i}$ denotes the comprehensive value of sample $i$. A bigger $\omega_{j}$ and $x_{i j}^{\prime}$ correspond to a bigger risk value.

$$
c_{i}=\sum_{j=1}^{n} \omega_{j} x_{i j}^{\prime}
$$

\section{Results}

In this study, we comprehensively evaluated the economic, transport infrastructurerelated, policy-related, eco-environmental, and disaster-related risks of the research regions, and their risk degrees are shown in Table 4. More detailed risk degrees of the third-level indices are shown in Appendix A. 
Table 4. Risk degrees of the research regions.

\begin{tabular}{ccccccc}
\hline Research Regions & ER & TR & PR & EER & DR & CR \\
\hline Artem & 0.255 & 0.076 & 0.006 & 0.075 & 0.034 & 0.445 \\
Vladivostok & 0.141 & 0.030 & 0.000 & 0.155 & 0.082 & 0.408 \\
Nakhodka & 0.273 & 0.059 & 0.000 & 0.117 & 0.074 & 0.0324 \\
Ussuriyskiy & 0.242 & 0.067 & 0.017 & 0.119 & 0.204 & 0.045 \\
Nadezhdinskiy & 0.365 & 0.080 & 0.000 & 0.174 & 0.033 & 0.695 \\
Oktyabr & 0.346 & 0.075 & 0.017 & 0.189 & 0.042 & 0.609 \\
Pogranichnyy & 0.285 & 0.077 & 0.017 & 0.249 & 0.060 & 0.647 \\
Khasanskiy & 0.272 & 0.049 & 0.017 & 0.182 & 0.043 & 0.631 \\
Shkotovskiy & 0.320 & 0.075 & 0.011 &
\end{tabular}

Note: ER, TR, PR, EER, DR, and CR represent the economic risk, the transport infrastructure-related risk, the policy-related risk, the disaster-related risk, and the comprehensive risk, respectively. The value represents the degree of the risk: the bigger the value, the bigger chance the region may encounter the risk.

\subsection{Economic Risk}

According to the results, the economic risk of the research area is mainly manifested in the following aspects.

- The economic development is poor, and construction funds and materials may be insufficient

The economic development in the study area is poor, and the monthly income from work per capita is less than 1000 USD. Vladivostok, the most economically developed region, had a monthly income from work per capita of only 888 USD in 2017 and a total fixed asset investment of 730 million USD, which was only three-fifths and 1/50, respectively, the amounts of Moscow. The region with the lowest level of economic development, Pogranichnyy, had a monthly income from work per capita and a fixed asset investment of 476 USD and 1.06 million USD, respectively-less than two-fifths and 1/100 the values of Moscow. Meanwhile, the dissolution of the Soviet Union led to the collapse of Russia's industrial system, and labor force transferred rapidly to areas with tertiary industry, showing a high proportion of tertiary industry to be seriously lagging [57]. Among the research regions, only the proportions of industry in Shkotovskiy and Artem were above 50\%, while all other regions were below $30 \%$. The poor economic development, insufficient investments, and industrial lag in the area may lead to a lack of sufficient funds and raw materials to construct the Primorsky No. 1 and No. 2 international transport corridors.

- The sparsely distributed and aging population and the problems of outflow and poor mineral resources in some regions limit economic vitality, which makes it difficult to form an agglomeration economy and reduces the overall return on investment of the corridor.

The study area is sparsely populated, and the population is elderly. Vladivostok, which has the largest population among the research regions, only had a population of 633,000 in 2017. Pogranichnyy, the region with the smallest population, has only 22,000 people. However, the proportions of the elderly in all research regions were higher than $18 \%$, thus exacerbating the social burden and reducing economic vitality. Population outflow is also a serious problem. In 2017, the outflowing populations of Nakhodka, Khasanskiy, and Pogranichnyy were 1761, 441, and 110, respectively, accounting for $17.73 \%$, $14.3 \%$, and $4.9 \%$ of their respective total populations. This has led to a shortage of human resources and limited regional economic vitality and growth, which have restrained the formation and development of an agglomeration economy. Some regions are also poor in mineral resources. For instance, there are no large mineral reserves in Oktyabr. This will make it more challenging to attract investments, which will limit the area's development and reduce the overall return on investment for the corridor. 
- The living standards in some regions are poor, which affects the safety of the construction and operation of the transport corridors

The living standards in some regions, such as Nadezhdinskiy, Pogranichnyy, Nakhodka, and Oktyabr, are poor. For Nadezhdinskiy, the region with the poorest living standards, the number of doctors per 10,000 people, beds per 10,000 people, and people per bed were $25.8,32.8$, and 305, respectively, in 2017. Here, the first two indices are much lower than the average for Russia $(47.5,80.5)$, while the third is much higher than the average (124.2). Crime in these research regions is also much worse than the average for Russia. In 2017, the average number of crimes for Russia per 10,000 people was 140.2, but the rates of all the research regions were much higher. The region with the worst crime, Oktyabr, had 289 crimes per 10,000 people, which is twice that of the average for Russia. Even the region with the lowest crime, Pogranichnyy, recorded 160 crimes per 10,000 people. The poor social situation in the area increases instability during the construction and operation of the international transport corridor and negatively affects safety.

The degrees of economic risk among regions in the research area are, in descending order, Nadezhdinsky, Oktyabr, Shkotovskiy, Pogranichnyy, Nakhodka, Khasanskiy, Artem, Ussuriyskiy, and Vladivostok, with values of $0.3652,0.3464,0.3196,0.2846,0.2733,0.2720$, $0.2551,0.2417$, and 0.1407 , respectively. By applying the method of equal interval division, we classified economic risk into three categories: key prevention and control (KPC), moderate prevention and control (MPC), and general prevention and control (GPC). The spatial distribution of economic risk is shown in Figure 2. Nadezhdinskiy, Oktyabr, Shkotovskiy, and Pogranichnyy are KPC regions, Nakhodka, Artem, Khasanskiy, and Ussuriyskiy are MPC regions, and only Vladivostok is a GPC region.

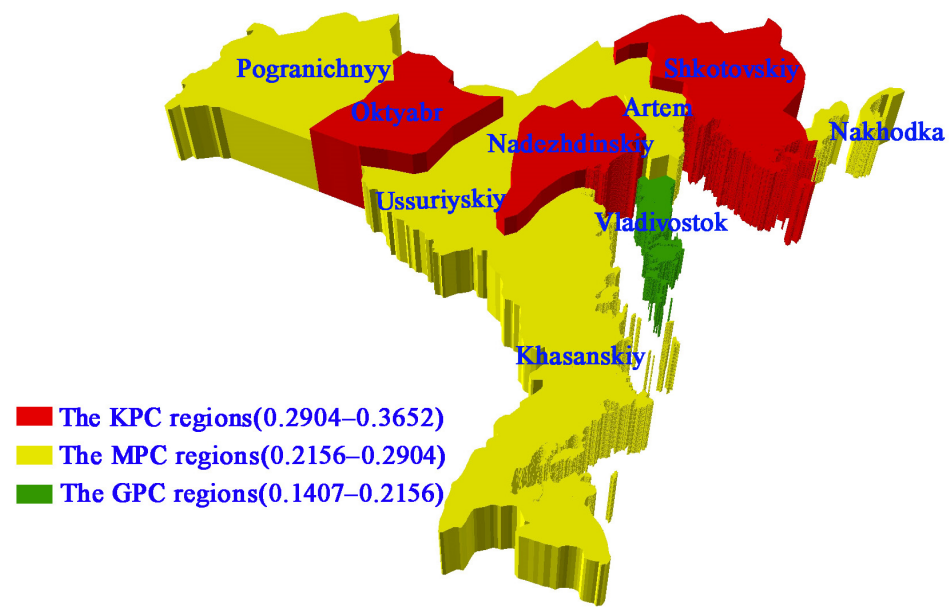

Figure 2. Patterns of the spatial distribution of economic risk.

\subsection{Transport Infrastructure-Related Risk}

The transport infrastructure is weak, and the cost of the transport corridor is massive. The railway and highway infrastructure of the research area is poor. Only the Vladivostok-Nadezhdinskiy-Ussuriyskiy railway is federal (capable of long distances with a relatively large transport capacity). The Vladivostok-Artem-Shkotovskiy-Nakhodka railways, Ussuriyskiy-Oktyabr-Pogranichnyy railways, and Nadezhdinskiy-Khasanskiy railways are all traditional railways (mainly from mines to a city or port or for military use). Only Shkotovskiy has an electric train (a suburban train at a low speed with a large number of stops). The road density and weight of the transported goods in Vladivostok, the city with the highest values for these factors, were only $14.27 \mathrm{~km} / \mathrm{km}^{2}$ and 1.5 million tons, respectively, in 2017. The road densities of the research regions (except Vladivostok) were all lower than $2 \mathrm{~km} / \mathrm{km}^{2}$. The goods transported in those areas were all lower than 0.5 million tons, excluding Nakhodka and Ussuriyskiy, with goods between 0.5 and 1 million tons. Khasanskiy and Shkotovskiy transported even less than 0.05 million 
tons per year. According to "The Development Construction of the Primorsky No. 1 and No. 2 International Transport Corridors," by 2030, the corridors will transport 45 million tons of grain. Thus, it is crucial to carry out the large-scale construction, upgrading, and modernization of railways and highways along the corridors, thus leading to massive costs for the construction of the corridors.

The degrees of transport infrastructure-related risk among regions in the research area are, in descending order, Nadezhdinskiy, Pogranichnyy, Artem, Oktyabr, Shkotovskiy, Ussuriyskiy, Nakhodka, Khasanskiy, and Vladivostok, with values of $0.0800,0.0768,0.0756$, $0.0746,0.0745,0.0673,0.0593,0.0490$, and 0.0302, respectively. Nadezhdinskiy, Pogranichnyy, Artem, Oktyabr, Shkotovskiy, and Ussuriyskiy belong to the KPC regions, Nakhodka, Khasanskiy belong to the MPC regions, and Vladivostok belongs to the GPC region (Figure 3).

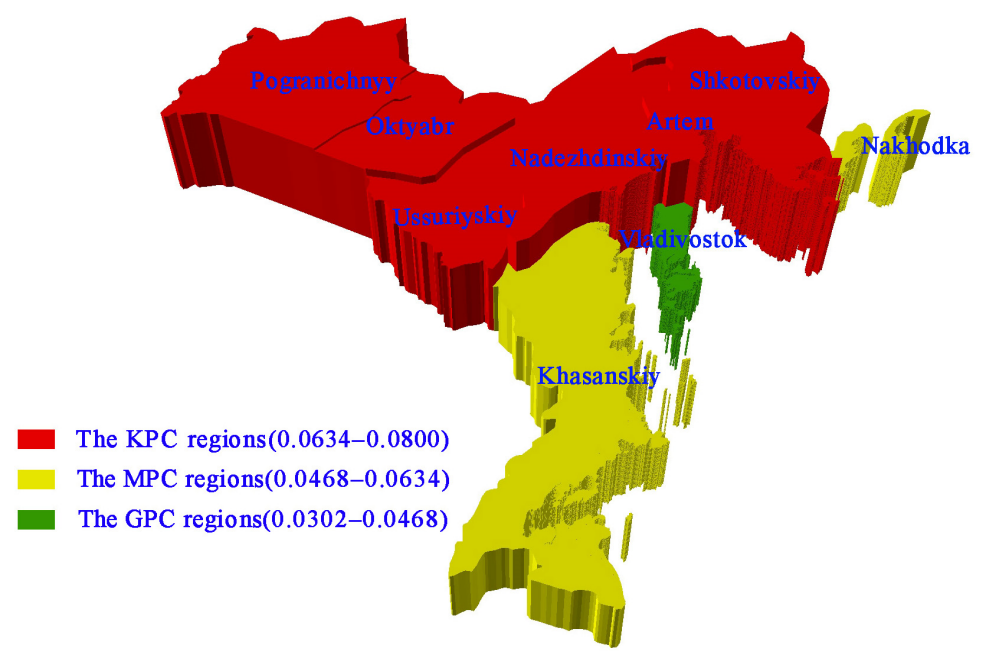

Figure 3. Patterns of the spatial distribution of transport infrastructure-related risk.

\subsection{Policy-Related Risk}

Although the Russian government has issued a series of policies and plans to promote regional development and transport construction, inland regions derive limited benefits from them, and the inland regions may not have sufficient incentives or funds to carry out large-scale transport construction. Russia has paid more attention to the Far East region due to the global economic integration and sanctions imposed on the area by Western countries-particularly on Primorsky. A series of policies and plans to boost regional economic development have been issued, including the "Free Distribution Act of Russian Far East Land" [58], "Socio-economic Development Strategy of Russian Far East and Baikal Area before 2025" [59], "National Planning of the Russian Federation for Social and Economic Development in the Far East and Baikal Region" [60], and "Conception on the Development of Border Areas in the Russian Far East Federal Region and the Baikal Region" [61] issued by the federal government, as well as the "Vladivostok Agglomeration Development Project" [62] issued by the Vladivostok municipal government. Moreover, with the increasingly close cooperation between China and Russia, the Chinese and Russian governments co-issued the "Sino Russian Cooperative Development Plan in the Far East of Russia (2018-2024)" [20]. The aim of this plan is to co-develop multiple projects, such as assembling and producing equipment for the manufacture, storage, transport, and unloading of liquefied natural gas (LNG) in the Vladivostok freeport, manufacturing acetic acid near the Nakhodka mineral fertilizer plant, a coal loading synthesis construction project at Vostochnyy port, and the Nakhodka seaport renovation project. The East Economic Forum has also been held annually in Vladivostok to open the Russian Far East to investors.

Primorsky holds a prominent strategic position in Northeast Asia and the global transport system. Therefore, in addition to regional development policies and plans, the 
Russian federal government also issued special transport policies for Primorsky, including the "Vladivostok Free Port Policy" [63] and the "Nakhodka Transport Hub" [62], to promote the development of the transport, logistics, and warehousing industries.

In summary, the governments at different levels have issued a series of policies and plans to promote the development of Primorsky. However, due to differences in regional features and levels of development, the regions tend to benefit differently from these policies. Current policies mainly target costal port regions, such as Vladivostok and Nakhodka, while inland regions, such as Ussuriysk and Oktyabr, derive limited benefits from them. Therefore, such areas may not have sufficient policy incentives or funds to carry out large-scale transport construction, which will constrain the construction of the two international transport corridors. We combined scores for the above regional and special development policies and plans. In ascending order, the regions scored as follows: Ussuriyskiy ( 6 points), Oktyabr (6 points), Pogranichnyy (6 points), Khasanskiy (6 points), Shkotovskiy (7 points), Artem (8 points), Nadezhdinskiy ( 9 points), Nakhodka (9 points), and Vladivostok (9 points). Their respective degrees of policy-related risk were determined as $0.0168,0.0168,0.0168,0.0168,0.0112,0.0056,0,0$, and 0 . Similarly, we divided policy-related risks into KPC, MPC, and GPC. Ussuriyskiy, Oktyabr, Pogranichnyy, and Khasanskiy are the KPC regions, Shkotovskiy is an MPC region, and Vladivostok, Nakhodka, Nadezhdinskiy, and Artem are GPC regions (Figure 4). Regional development policies for the KPC regions need to be formulated to provide policy incentives and support for the construction of the transport corridors.

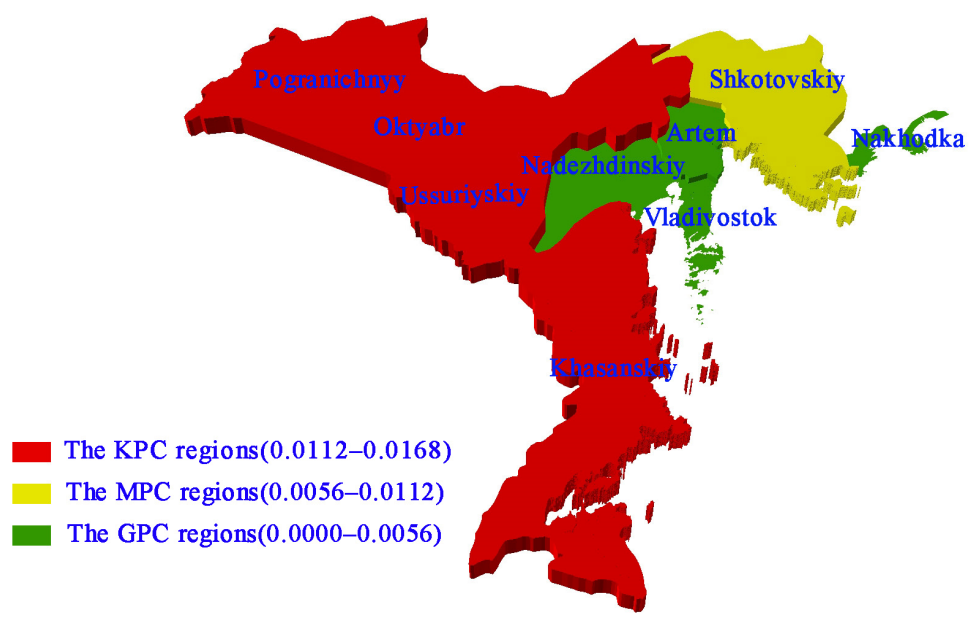

Figure 4. Pattern of the spatial distribution of policy-related risk.

\subsection{Eco-Environmental Risk}

The ecological environment of the research area is good, so the construction of the two international transport corridors may damage it and threaten its biodiversity. The area features high forest coverage. By interpreting the Land Cover CCI, the forest coverage rates of seven research regions, including Khasanskiy, Shkotovskiy, and Nadezhdinskiy, were found to be higher than $70 \%$; those of Khasanskiy and Shkotovskiy were even higher than $80 \%$; and only those of Vladivostok and Oktyabr were lower than $70 \%$, with $69.77 \%$ and $37.97 \%$, respectively. Notably, such areas included the Leopard National Park (located along the borders of Vladivostok, Ussuriyskiy, Nadezhdinskiy, and Khasanskiy), the Far East Marine Reserve (located along the border of Vladivostok and Khasanskiy), and the Ussuriyskiy Natural Reserve (along the border of Ussuriyskiy and Shkotovskiy). These areas feature many rare species of animals and plants, such as the Far East leopard, Siberian tiger, Himalayan bear, ginseng, and rock cabbage. However, the construction of the transport corridors is very likely to cause damage to the surface vegetation and ecosystems and to divide the animal habitat, thus affecting the ecosystem's service functions and biodiversity [40-42]. Therefore, there is a risk of ecological damage. In addition, these 
research regions are all in the early or middle stages of industrialization, and emissions of pollutants in the areas are low. However, the construction and operation of the transport corridors will inevitably consume a large amount of resources and emit such environmental pollutants as exhaust gas, wastewater, and construction waste. Moreover, the consequent economic development introduced by the construction and operation of the transport corridors will increase emissions further. Therefore, policies to control and prevent ecological environment damage are needed.

Based on the above results, the degrees of eco-environmental risk posed to regions in the area are, in descending order, Khasanskiy, Nadezhdinskiy, Pogranichnyy, Shkotovskiy, Oktyabr, Vladivostok, Ussuriyskiy, Nakhodka, and Artem, with values of $0.2488,0.2042$, $0.1894,0.1820,0.1738,0.1551,0.1191,0.1172$, and 0.0747 , respectively. Among the research regions, Khasanskiy and Nadezhdinskiy are KPC regions (Figure 5). Pogranichnyy, Shkotovskiy, Oktyabr, and Vladivostok are MPC regions, and Ussuriyskiy, Nakhodka, and Artem are GPC regions.

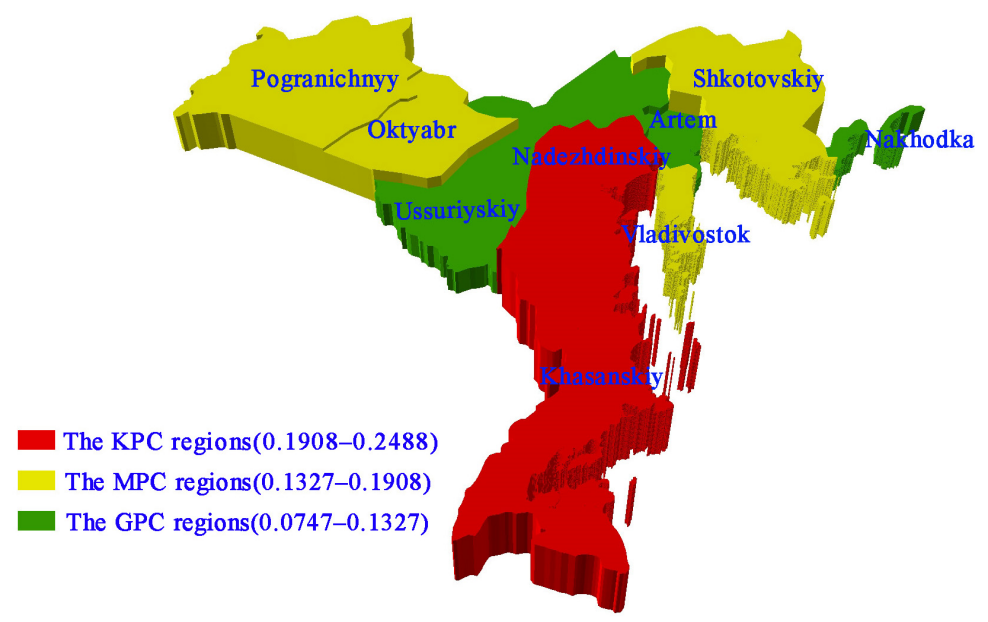

Figure 5. Pattern of the spatial distribution of eco-environmental risk.

\subsection{Disaster-Related Risk}

The present research area is prone to disasters such as floods, tsunamis, and landslides, which increase the difficulty and costs of construction of the transport corridors and reduce safety. The research area is located in the southern part of Primorsky, adjacent to the Sea of Japan (East Sea). According to the research on disasters and their grades in the "Atlas of Primorsky Kray" [48] and the "Ecological Atlas of Russia" [49], grades of floods are divided into five categories: extremely dangerous, very dangerous, dangerous, medium danger, and low danger. Among the nine regions, only Pogranichnyy belongs to the very dangerous category; the other eight regions all belong to the extremely dangerous category. Grades of landslides were also divided into five categories: $<6,6-7,7,7-8,>8$. Only Oktyabr and Pogranichnyy belong to the first two categories; the other seven regions all belong to the 7-8 and $>8$ categories. Meanwhile, since Vladivostok and Nakhodka are coastal regions, they have a high risk of tsunamis. According to the research, the wave height and wave lengths of tsunamis in Vladivostok can be as great as 2.5 and $200 \mathrm{~m}$, respectively, while those in Nakhodka can be 3 and $100 \mathrm{~m}$, respectively. Moreover, regions such as Pogranichnyy are at a high risk of earthquakes and gully erosions (as shown in Table 5). Due to the high frequency natural and geological disasters in the research area, comprehensive geological and geomorphic explorations need to be carried out, and disaster early warning, prevention, and control systems need to be established, thus increasing the construction difficulty and costs and reducing safety. 
Table 5. Types and grades of disasters in the research area.

\begin{tabular}{|c|c|c|c|c|c|}
\hline & Flood Grade & Landslide Grade & $\begin{array}{c}\text { Tsunami (Wave } \\
\text { Height/Wave Length) }\end{array}$ & Earthquake Grade & $\begin{array}{l}\text { Gully Erosion } \\
\text { Grade }\end{array}$ \\
\hline Artem & $\begin{array}{l}\text { Extremely } \\
\text { dangerous }\end{array}$ & $7-8$ & - & - & Very low \\
\hline Vladivostok & $\begin{array}{l}\text { Extremely } \\
\text { dangerous }\end{array}$ & $7-8$ & $2.5 / 200$ & $6-7$ & Very low \\
\hline Nakhodka & $\begin{array}{l}\text { Extremely } \\
\text { dangerous }\end{array}$ & 8 & $3 / 100$ & $7-8$ & Very low \\
\hline Ussuriyskiy & $\begin{array}{l}\text { Extremely } \\
\text { dangerous }\end{array}$ & $7-8$ & - & - & Very low \\
\hline Nadezhdinskiy & $\begin{array}{l}\text { Extremely } \\
\text { dangerous }\end{array}$ & $7-8$ & - & - & Medium \\
\hline Oktyabr & $\begin{array}{l}\text { Extremely } \\
\text { dangerous }\end{array}$ & 6 & - & - & Medium \\
\hline Pogranichnyy & Very dangerous, & 7 & - & $7-8$ & Medium \\
\hline Khasanskiy & $\begin{array}{l}\text { Extremely } \\
\text { dangerous }\end{array}$ & $7-8$ & - & $6-7$ & Medium \\
\hline Shkotovskiy & $\begin{array}{l}\text { Extremely } \\
\text { dangerous }\end{array}$ & $7-8$ & - & $6-7$ & - \\
\hline
\end{tabular}

Note: Earthquake grades were divided into three categories: 6-7, 7-8, and 8-9. Gully erosion grades were divided into four categories: high, medium, low, and very low. "-" for No data.

According to the above, the degrees of disaster-related risks among regions are, in descending order, Vladivostok, Nakhodka, Khasanskiy, Nadezhdinskiy, Shkotovskiy, Pogranichnyy, Artem, Ussuriyskiy, and Oktyabr, with values of 0.0820, 0.0740, 0.0600, $0.0454,0.0434,0.0417,0.0343,0.0343$, and 0.0330 , respectively. Vladivostok and Nakhodka are KPC regions, Khasanskiy is an MPC region, and Nadezhdinskiy, Shkotovskiy, Pogranichnyy, Artem, Ussuriyskiy, and Oktyabr are GPC regions (Figure 6).

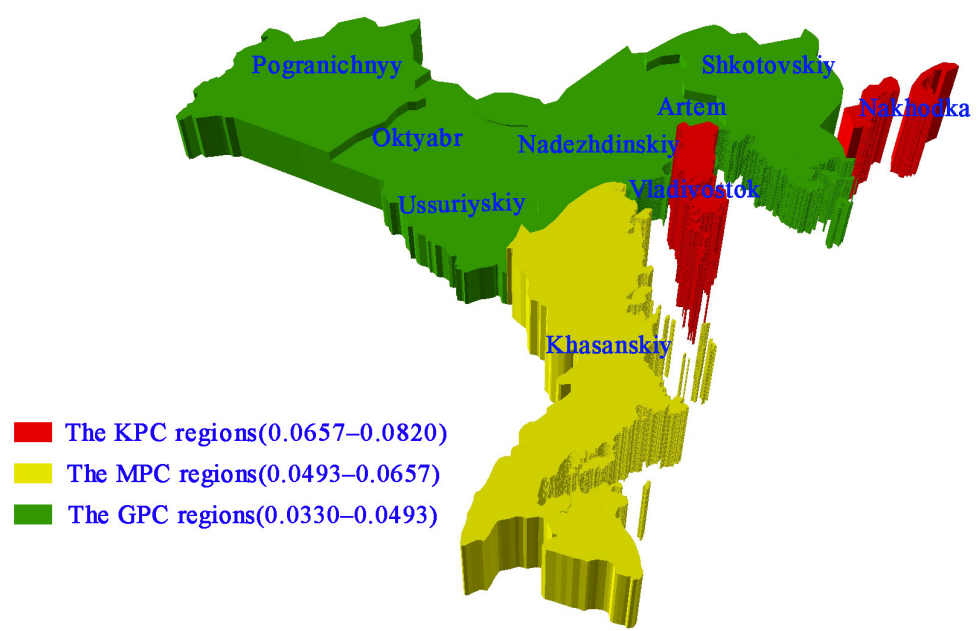

Figure 6. Pattern of the spatial distribution of disaster-related risk.

\subsection{Comprehensive Risk}

By integrating the economic, transport infrastructure-related, policy-related, ecoenvironmental, and disaster-related risks, we obtained a comprehensive degree of risks. In terms of risk, in descending order, the regions are Nadezhdinskiy, Khasanskiy, Oktyabr, Shkotovskiy, Pogranichnyy, Nakhodka, Ussuriyskiy, Artem, and Vladivostok, with respective values of $0.6948,0.6466,0.6446,0.6308,0.6092,0.5238,0.4792,0.4454$, and 0.4080 . Nadezhdinskiy, Khasanskiy, Oktyabr, Shkotovskiy, and Pogranichnyy are KPC regions in terms of comprehensive risk, Nakhodka is an MPC region, and Ussuriyskiy, Artem, and Vladivostok are GPC regions (Figure 7). 


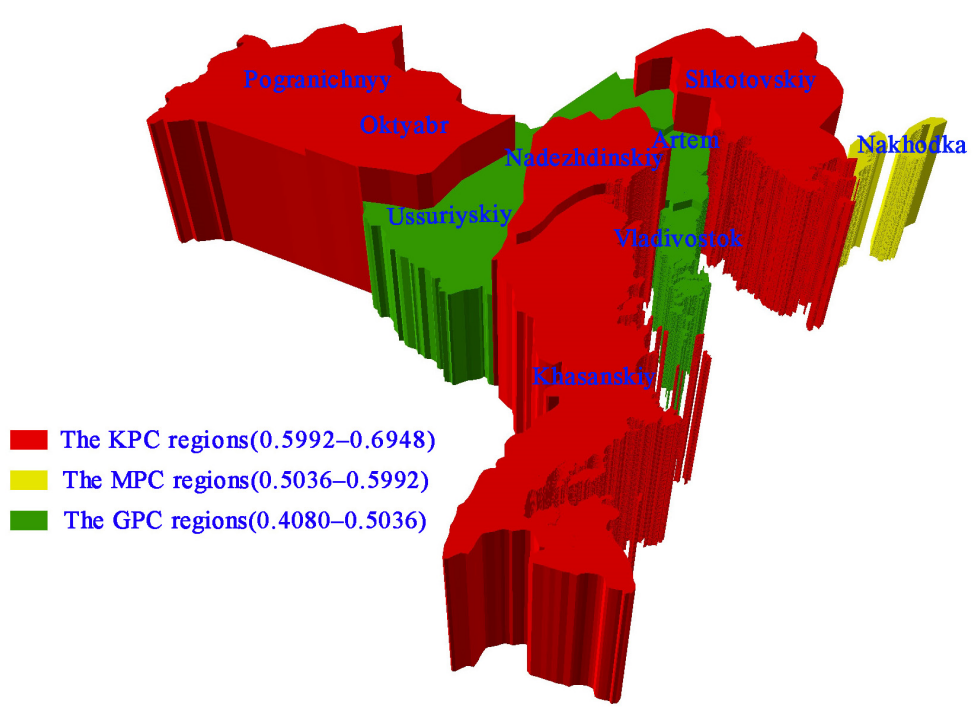

Figure 7. Pattern of the spatial distribution of comprehensive risk.

\section{Discussion}

By comprehensively reviewing the main risk-related factors in constructing transport corridors and then analyzing the current economic, transport, and regional policies along with the eco-environment and geological status of the research area, we identify that economic, transport infrastructure-related, policy-related, eco-environmental, and disasterrelated risks are the main risks for the construction of the Primorsky No. 1 and No. 2 international transport corridors. Then, by establishing a comprehensive evaluation system for these risks, we quantitatively evaluate the degrees of these risks and reveal their spatial distribution pattern. These risks inhibit the construction progress of the transport corridors. To promote the construction of the transport corridors, there is an urgent demand to formulate the targeted mitigation policies to prevent and control the above risks.

(1) The KPC regions of economic risk include Nadezhdinskiy, Oktyabr, Shkotovskiy, and Pogranichnyy. Due to these regions' backward economic and industrial development as well as sparsely and aging population, they may not have sufficient funds to construct the corridors. To mitigate the economic risk of these regions, China and Russia governments should innovate modes of cooperation through exchanging resources for funds and exchanging property for funds. Powerful Chinese construction companies, such as the China State Construction Engineering Corporation, and Longjian Road and Bridge Company Limited, can provide funds, technology, talent, equipment, and raw materials to construct, operate, and maintain the transport infrastructure. In exchange, these regions can transfer the ownership, administrative rights, and management rights of the railways and highways, as well as the development rights for local mineral and energy resources to Chinese enterprises. By exchanging resources and developing their comparative advantages, China and Russia can together construct the transport corridors and achieve a win-win outcome. Meanwhile, a special foundation for Primorsky No. 1 and No. 2 international transport corridors should be established, in addition to government allocations, capital investments from large Chinese and Russian road and bridge companies, as well as social donations should be sought, so as to broaden the channels of funding sources and mitigate economic risk.

(2) The KPC regions of infrastructure-related risk include Nadezhdinskiy, Pogranichnyy, Artem, Oktyabr, Shkotovskiy, and Ussuriyskiy, due to their poor infrastructure. Constructing highways and roads in these regions demands large-scale construction, upgrading, and modernization of the railways and roads infrastructure, which will increase the construction difficulty of the transport corridors, and the extremely cold weather of these regions will further exacerbate the construction difficulties. To 
mitigate the infrastructure-related risk in these regions, the advanced construction technologies and equipment applied in alpine region, such as that achieved and used in the construction of the Qinghai-Tibet railway, should be introduced so as to overcome construction difficulties in these regions and promote the construction progress.

(3) The KPC regions of policy-related risk are distributed in inland regions such as Ussuriyskiy, Oktyabr, Pogranichnyy, and Khasanskiy. Since the issued policies and plans mainly target costal port cities such as Vladivostok and Nokhodka, these inland regions derive limit benefits from them, and they may also not have sufficient policy incentives to carry out large-scale transport construction. To mitigate the policyrelated risk in these regions, targeted polices for regional development, specific transport construction, and talent attracting for inland regions should be formulated so as to improve policy support for the construction of the corridors.

(4) The KPC regions of eco-environmental risk include Khasanskiy and Nadezhdinskiy, due to their good ecological environment. The construction and operation of the transport corridors will interfere with the ecological environment and patterns of the ecosystem. To mitigate eco-environmental risk in these regions, firstly, design of the transport corridors should try to avoid zones with dense forests and natural reserves. For natural reserves such as the Leopard National Park and Far East Marine Reserve, buffer zones should be designated, and the transport corridors should be located outside those buffer zones to minimize disturbances to the ecological system. Third, for dotted forests, grassland, lakes, and wetlands that the transport corridor construction cannot avoid, advanced engineering techniques, such as viaducts, tunnels, bridges, ramp transitions, and noise barriers, can be applied to minimize ecological and environmental damage. Moreover, during the construction and operation of the transport corridors, green technology should be used for the efficient use and recycling of resources to reduce the emission of pollutants.

(5) The KPC regions of disaster-related risk include Vladivostok and Nakhodka. These two regions are adjacent to the Sea of Japan (East sea) and are prone to disasters such as floods, tsunamis, and landslides, which increase the difficulty of constructing transport corridors. To mitigate the disaster-related risk in these regions and guarantee the safe construction and operation of the transport corridors, the Sino-Russian governments should establish early warning, prevention, and control systems for such disasters, and they should share the relevant information in real time and make emergency prevention and control plans.

Meanwhile, to validate our research results, another widely used method, the AHP method, was applied to determine the weights of the indices. To compare the spatial distribution of these risks by the APH method with that obtained by the entropy method, here, we firstly established hierarchical models for these five risks and acquired the weights of the indices; secondly, we calculated the risk degrees of the research regions by applying Formulas (1) and (6); thirdly, we also divided the degrees of each risk into three categories by the method of equal intervals. The spatial distribution of these risks is shown in Figure 8. By comparing Figures $2-6$ and 8, it can be seen that the results obtained by the AHP method are basically the same as those obtained by the entropy method. The KPC regions of economic risk, policy-related risk, eco-environmental risk, and disaster-related risk are the same; only that of the transport infrastructure-related risk is a little different from that obtained by the entropy method, with Ussuriyskiy as an MPC region rather than an KPC region. However, since these two methods are totally different, such deviation is reasonable. The uniformity of the results obtained by the two methods proves the validation of our research. 


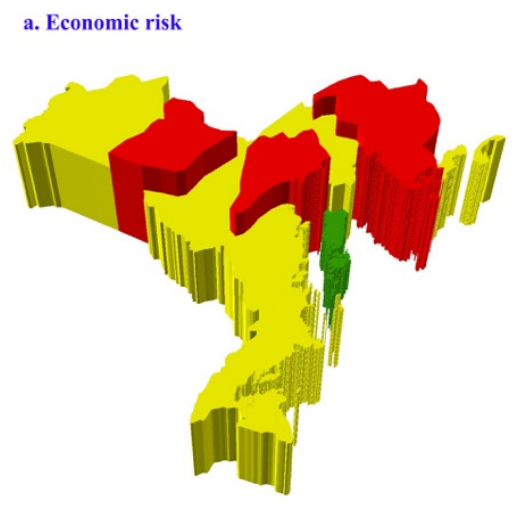

d. Eco-environment risk

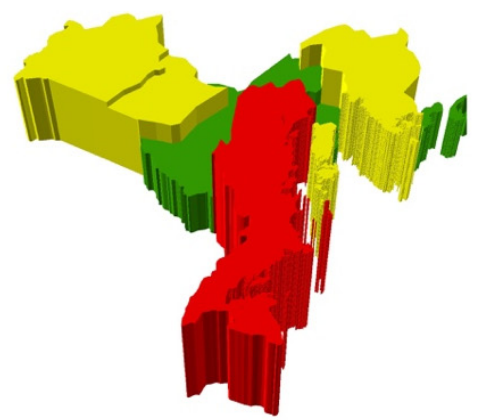

b. Transport infrasturcture-related risk

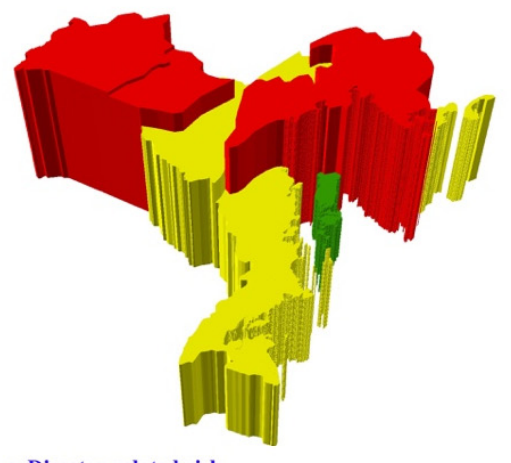

e. Disaster-related risk

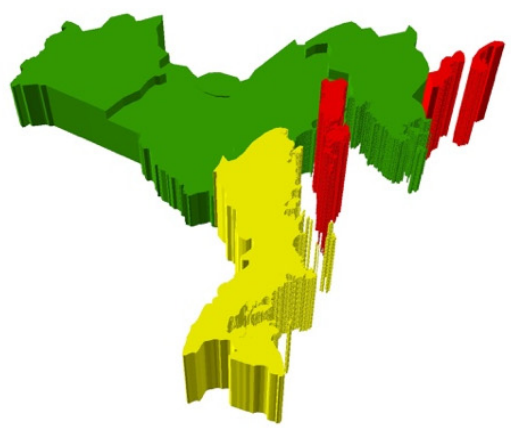

c. Policy-related risk

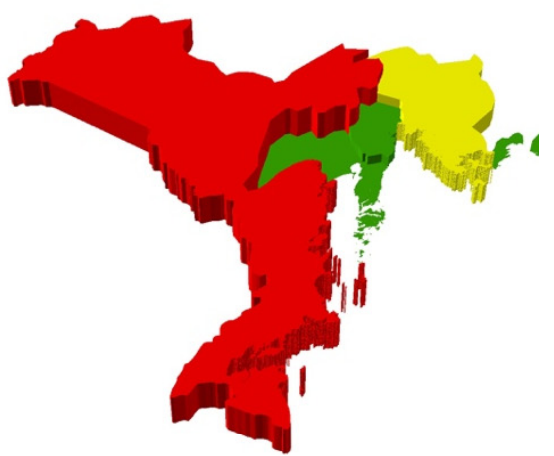

The MPC regions
The KPC regions

The GPC regions

Figure 8. The spatial distribution pattern of the economic, transport infrastructure-related, policy-related, eco-environmental, and disaster-related risks by the Analytic Hierarchy Process (AHP) method.

\section{Conclusions}

The construction of the Primorsky No. 1 and No. 2 international transport corridors is of great strategic significance to China and Russia. These corridors will solve the problem of the absence of an estuary in Northeast China by sailing from Russian ports and greatly improve Russia's position in the world's transport system as well as greatly promote the economic development of the regions along the two corridors. However, existing studies are mainly focused on the strategic significance of the corridors, but there have been few studies on the identification, evaluation, and spatial distribution of construction risks, leading to a lack of scientific support for the construction of the corridors and inhibiting the constructing progress. Thereby, we firstly comprehensively reviewed the main risk-related factors for constructing transport corridors, railways, and roads, analyzed the current economic, transport, and regional policies along with the eco-environmental and geological status of the research area, and identified the main risks for constructing of the Primorsky No. 1 and No. 2 international transport corridors. It is found that economic, transport infrastructure-related, policy-related, eco-environmental, and disasterrelated risks are the main risks for the construction of the transport corridors. Then, we established a comprehensive evaluation system for these risks. By applying the entropy method, we evaluated the degrees of each risk in the research regions, revealed their spatial distributions, and proposed mitigation policies to prevent and control those risks. This research provides scientific support for risk prevention and mitigation in the construction of the Primorsky No. 1 and No. 2 international transport corridors, and it promotes their construction progress. Meanwhile, the comprehensive evaluation system we established can be applied in risk evaluation for the construction of other transport corridors, railways, and roads.

The KPC regions of economic risk include Nadezhdinskiy, Oktyabr, Shkotovskiy, and Pogranichnyy. The innovative cooperation mode of exchanging resources for funds and exchanging property for funds should be established. Channels of funding sources 
should be broadened to mitigate the economic risk in these regions. The KPC regions of infrastructure-related risk include Nadezhdinskiy, Pogranichnyy, Artem, Oktyabr, Shkotovskiy, and Ussuriyskiy. The advanced technologies and equipment applied in alpine regions should be introduced in to overcome construction difficulties and promote the construction progress in these regions. The KPC regions of policy-related risk are distributed in inland regions such as Ussuriyskiy, Oktyabr, Pogranichnyy, and Khasanskiy. Further targeted policies for these inland regions should be formulated. The KPC regions of eco-environmental risk include Khasanskiy and Nadezhdinskiy. Design of the transport corridors should try to avoid zones with dense forests and natural reserves in these regions; buffer zones should be designated around natural reserves and national park; advanced engineering techniques such as viaducts, tunnels, and bridges, and green, efficient and circular technology should be applied to minimize ecological and environmental damage. The KPC regions of disaster-related risk include Vladivostok and Nakhodka. Early warning, prevention, and control systems for disasters should be established to share the relevant information in real time and make emergency prevention and control plans.

There are limitations to this research. (1) Since some kinds of data are not public, some indices are not included in the comprehensive evaluation system we establish. For instance, the density, transported volume, and other data on railways and ports are not included in the evaluation system due to lack of data. Meanwhile, to validate the construction risks we identify and the evaluation system we establish, it is better to ask the opinions of some government employees who work in the transport department of regions along the two transport corridors as well as native scientists who major in the construction of transport. Therefore, we sought professional advice from two scientists in the Pacific Institute of Geography, Russian Academy of Sciences (located in Primorsky, Russia) who major in construction of transport network. They provided valuable advice and helped establish the current evaluation system. The inclusion of such native scientists in establishing the evaluation system helps improve its validity. However, until now, we could not reach any government employees to validate the construction risks we identify or the evaluation system we establish. (2) The data applied in the research are from the year 2017, due to the changing global and political risk factors, the policy score of the research regions may be a little different from now, but the pattern of policies that mainly target coastal regions has not changed nor have the patterns of economic, transport infrastructure-related, ecoenvironmental, and disaster-related situations. The results of the research are applicable and can provide scientific support for the construction of the two transport corridors.

In the future, we will further improve the comprehensive evaluation system and explore methods to quantify the qualitative index. We also will study in detail the spatial distribution of each risk in each region from a micro-scale and formulate systematical countermeasures, outlines, plans, and platforms to prevent, control, and mitigate risks, so as to provide more detailed and solid scientific support for the construction of the corridors.

Author Contributions: Conceptualization, F.L. and S.D.; Data curation, T.B., and Q.L.; Formal analysis, Y.Y.; Investigation, Y.Y., T.B., F.L., S.D., H.C., Y.L. and Z.L.; Methodology, Y.Y. and Q.L.; Resources, T.B.; Supervision, F.L. and S.D.; Validation, Y.Y.; Visualization, Q.L.; Writing-original draft, Y.Y.; Writing-review and editing, F.L., and S.D. All authors have read and agreed to the published version of the manuscript.

Funding: This research was funded by Science and Technology Basic Resources Survey Project, Grant number 2017FY101304; Strategic Priority Research Program (A) of Chinese Academy of Sciences, Grant number XDA20030203; Innovation Academy for Green Manufacture, Chinese Academy of Sciences (Grants No. IGAM-2019-A16-2); National Natural Science Foundation of China, Grant number 42071282.

Institutional Review Board Statement: Not applicable.

Informed Consent Statement: Not applicable.

Data Availability Statement: The data presented in this study are available on request from the corresponding author. 
Acknowledgments: We would like to thank the editors and the anonymous reviewers' help and guidance.

Conflicts of Interest: The authors declare no conflict of interest.

\section{Appendix A}

Table A1. Risk degrees of all the third-level indices in the research regions.

\begin{tabular}{|c|c|c|c|c|c|c|c|c|c|}
\hline Indices & Artem & Vladivostok & Nakhodka & Ussuriyskiy & Nadezhdinskiy & Oktyabr & Pogranichnyy & Khasanskiy & Shkotovskiy \\
\hline 1 & 0.014 & 0.000 & 0.012 & 0.012 & 0.016 & 0.016 & 0.016 & 0.016 & 0.016 \\
\hline 2 & 0.007 & 0.000 & 0.004 & 0.009 & 0.014 & 0.012 & 0.017 & 0.010 & 0.007 \\
\hline 3 & 0.016 & 0.000 & 0.012 & 0.015 & 0.016 & 0.016 & 0.016 & 0.016 & 0.014 \\
\hline 4 & 0.016 & 0.014 & 0.000 & 0.016 & 0.016 & 0.016 & 0.016 & 0.016 & 0.016 \\
\hline 5 & 0.016 & 0.000 & 0.015 & 0.016 & 0.016 & 0.016 & 0.016 & 0.016 & 0.016 \\
\hline 6 & 0.016 & 0.000 & 0.014 & 0.016 & 0.016 & 0.016 & 0.016 & 0.016 & 0.016 \\
\hline 7 & 0.001 & 0.000 & 0.014 & 0.013 & 0.016 & 0.017 & 0.017 & 0.016 & 0.016 \\
\hline 8 & 0.000 & 0.001 & 0.014 & 0.012 & 0.017 & 0.009 & 0.002 & 0.002 & 0.002 \\
\hline 9 & 0.006 & 0.014 & 0.016 & 0.011 & 0.014 & 0.016 & 0.016 & 0.015 & 0.000 \\
\hline 10 & 0.010 & 0.002 & 0.003 & 0.007 & 0.005 & 0.001 & 0.000 & 0.002 & 0.017 \\
\hline 11 & 0.000 & 0.001 & 0.001 & 0.01 & 0.001 & 0.002 & 0.002 & 0.003 & 0.001 \\
\hline 12 & 0.000 & 0.002 & 0.002 & 0.001 & 0.001 & 0.004 & 0.002 & 0.002 & 0.002 \\
\hline 13 & 0.000 & 0.001 & 0.003 & 0.004 & 0.001 & 0.005 & 0.002 & 0.001 & 0.002 \\
\hline 14 & 0.000 & 0.001 & 0.001 & 0.001 & 0.002 & 0.002 & 0.001 & 0.001 & 0.001 \\
\hline 15 & 0.000 & 0.003 & 0.001 & 0.001 & 0.003 & 0.003 & 0.001 & 0.001 & 0.002 \\
\hline 16 & 0.014 & 0.000 & 0.013 & 0.012 & 0.016 & 0.016 & 0.016 & 0.016 & 0.016 \\
\hline 17 & 0.009 & 0.017 & 0.014 & 0.000 & 0.008 & 0.008 & 0.003 & 0.007 & 0.007 \\
\hline 18 & 0.011 & 0.008 & 0.014 & 0.003 & 0.016 & 0.013 & 0.000 & 0.008 & 0.017 \\
\hline 19 & 0.008 & 0.017 & 0.009 & 0.006 & 0.005 & 0.000 & 0.001 & 0.006 & 0.005 \\
\hline 20 & 0.007 & 0.000 & 0.009 & 0.001 & 0.012 & 0.012 & 0.001 & 0.006 & 0.017 \\
\hline 21 & 0.016 & 0.012 & 0.015 & 0.011 & 0.015 & 0.016 & 0.000 & 0.014 & 0.013 \\
\hline 22 & 0.008 & 0.000 & 0.004 & 0.008 & 0.011 & 0.017 & 0.015 & 0.012 & 0.008 \\
\hline 23 & 0.004 & 0.004 & 0.015 & 0.000 & 0.000 & 0.004 & 0.009 & 0.017 & 0.004 \\
\hline 24 & 0.001 & 0.001 & 0.000 & 0.002 & 0.017 & 0.013 & 0.009 & 0.005 & 0.009 \\
\hline 25 & 0.011 & 0.000 & 0.006 & 0.007 & 0.017 & 0.013 & 0.015 & 0.008 & 0.009 \\
\hline 26 & 0.001 & 0.000 & 0.005 & 0.004 & 0.007 & 0.017 & 0.011 & 0.004 & 0.005 \\
\hline 27 & 0.006 & 0.001 & 0.003 & 0.007 & 0.010 & 0.017 & 0.000 & 0.012 & 0.001 \\
\hline 28 & 0.009 & 0.000 & 0.011 & 0.001 & 0.014 & 0.012 & 0.005 & 0.004 & 0.017 \\
\hline 29 & 0.001 & 0.000 & 0.002 & 0.000 & 0.005 & 0.003 & 0.001 & 0.000 & 0.017 \\
\hline 30 & 0.012 & 0.000 & 0.011 & 0.011 & 0.013 & 0.014 & 0.013 & 0.012 & 0.016 \\
\hline 31 & 0.009 & 0.015 & 0.013 & 0.007 & 0.013 & 0.000 & 0.017 & 0.008 & 0.005 \\
\hline 32 & 0.015 & 0.015 & 0.012 & 0.010 & 0.016 & 0.016 & 0.016 & 0.000 & 0.010 \\
\hline 33 & 0.013 & 0.012 & 0.003 & 0.013 & 0.017 & 0.002 & 0.012 & 0.000 & 0.014 \\
\hline 34 & 0.016 & 0.000 & 0.016 & 0.016 & 0.016 & 0.016 & 0.016 & 0.016 & 0.016 \\
\hline 35 & 0.015 & 0.000 & 0.015 & 0.016 & 0.016 & 0.016 & 0.016 & 0.016 & 0.016 \\
\hline 36 & 0.015 & 0.000 & 0.007 & 0.010 & 0.015 & 0.012 & 0.014 & 0.016 & 0.016 \\
\hline 37 & 0.014 & 0.015 & 0.005 & 0.013 & 0.016 & 0.014 & 0.015 & 0.000 & 0.010 \\
\hline 38 & 0.016 & 0.015 & 0.016 & 0.013 & 0.016 & 0.016 & 0.015 & 0.000 & 0.015 \\
\hline 39-48 & 0.006 & 0.000 & 0.000 & 0.017 & 0.000 & 0.017 & 0.017 & 0.017 & 0.011 \\
\hline 49 & 0.007 & 0.000 & 0.003 & 0.009 & 0.004 & 0.017 & 0.004 & 0.001 & 0.000 \\
\hline 50 & 0.010 & 0.009 & 0.010 & 0.010 & 0.012 & 0.000 & 0.011 & 0.012 & 0.016 \\
\hline 51 & 0.002 & 0.000 & 0.000 & 0.001 & 0.007 & 0.017 & 0.013 & 0.008 & 0.000 \\
\hline 52 & 0.004 & 0.003 & 0.017 & 0.000 & 0.002 & 0.002 & 0.000 & 0.007 & 0.001 \\
\hline 53 & 0.004 & 0.004 & 0.004 & 0.000 & 0.008 & 0.004 & 0.004 & 0.017 & 0.008 \\
\hline 54 & 0.008 & 0.013 & 0.013 & 0.000 & 0.008 & 0.000 & 0.000 & 0.017 & 0.004 \\
\hline 55 & 0.000 & 0.017 & 0.000 & 0.017 & 0.017 & 0.000 & 0.000 & 0.017 & 0.017 \\
\hline 56 & 0.000 & 0.017 & 0.000 & 0.017 & 0.000 & 0.000 & 0.000 & 0.017 & 0.000 \\
\hline 57 & 0.000 & 0.000 & 0.004 & 0.000 & 0.004 & 0.000 & 0.017 & 0.017 & 0.009 \\
\hline 58 & 0.000 & 0.000 & 0.000 & 0.017 & 0.013 & 0.004 & 0.008 & 0.017 & 0.000 \\
\hline 59 & 0.000 & 0.009 & 0.007 & 0.006 & 0.016 & 0.015 & 0.017 & 0.015 & 0.016 \\
\hline 60 & 0.007 & 0.007 & 0.002 & 0.000 & 0.015 & 0.014 & 0.017 & 0.014 & 0.015 \\
\hline
\end{tabular}


Table A1. Cont.

\begin{tabular}{|c|c|c|c|c|c|c|c|c|c|}
\hline Indices & Artem & Vladivostok & Nakhodka & Ussuriyskiy & Nadezhdinskiy & Oktyabr & Pogranichnyy & Khasanskiy & Shkotovskiy \\
\hline 61 & 0.000 & 0.013 & 0.014 & 0.012 & 0.016 & 0.016 & 0.016 & 0.016 & 0.016 \\
\hline 62 & 0.001 & 0.006 & 0.000 & 0.000 & 0.016 & 0.014 & 0.017 & 0.014 & 0.016 \\
\hline 63 & 0.000 & 0.008 & 0.010 & 0.009 & 0.016 & 0.016 & 0.016 & 0.015 & 0.016 \\
\hline 64 & 0.013 & 0.012 & 0.011 & 0.000 & 0.015 & 0.016 & 0.016 & 0.014 & 0.015 \\
\hline 65 & 0.000 & 0.006 & 0.012 & 0.010 & 0.016 & 0.016 & 0.016 & 0.015 & 0.015 \\
\hline 66 & 0.012 & 0.014 & 0.000 & 0.008 & 0.015 & 0.013 & 0.015 & 0.015 & 0.016 \\
\hline 67 & 0.006 & 0.017 & 0.010 & 0.002 & 0.003 & 0.009 & 0.001 & 0.000 & 0.001 \\
\hline 68 & 0.000 & 0.015 & 0.017 & 0.000 & 0.000 & 0.000 & 0.017 & 0.015 & 0.015 \\
\hline 69 & 0.012 & 0.012 & 0.016 & 0.012 & 0.012 & 0.000 & 0.008 & 0.012 & 0.012 \\
\hline 70 & 0.000 & 0.015 & 0.018 & 0.000 & 0.000 & 0.000 & 0.000 & 0.000 & 0.000 \\
\hline 71 & 0.000 & 0.018 & 0.001 & 0.000 & 0.000 & 0.000 & 0.000 & 0.000 & 0.000 \\
\hline 72 & 0.006 & 0.006 & 0.006 & 0.006 & 0.017 & 0.017 & 0.017 & 0.017 & 0.000 \\
\hline 73 & 0.016 & 0.016 & 0.016 & 0.016 & 0.016 & 0.016 & 0.000 & 0.016 & 0.016 \\
\hline
\end{tabular}

Note: 1-73 represent the corresponding third-level indices in Table 3, respectively. The value represents the risk value of each index. A bigger value corresponds to a bigger risk.

\section{References}

1. National Development and Reform Commission (NDRC). China and Russia Signed Memorandum of Understanding on Cooperation. Available online: http:/ / www.chinadevelopment.com.cn/fgw/2017/07/1157561.shtml (accessed on 11 February 2020).

2. Ministry of Commerce of the People's Republic of China (MOC). Russian Government Approves the Development Construction of "Primorsky No. 1" and "Primorsky No. 1" International Transport Corridor. Available online: http://www.mofcom.gov.cn/ article/i/jyjl/e/201701/20170102494758.shtml (accessed on 11 February 2020).

3. Liang, Z.M.; Chen, C. Study on Northeast Asia international cooperation and construction of the second Northeast Asia-Europe Land Bridge. Northeast Asia Forum 2012, 21, 59-64.

4. Li, Z.F.; Liu, S.S. Docking of "Polar Silk Road" in Northeast China. Econ. Rev. J. 2018, 5, 61-67.

5. Dou, B. On the Polar Silk Road and jointly building of blue economic passage for Arctic route between China and Russia. Northeast Asia Econ. Res. 2018, 2, 5-14.

6. Sazonov, S.L. Russia and China in Eurasian transport corridor. Asia Afr. Today 2014, 8, 12-18.

7. Romanova, G. Russian Far East-Northeast China: Trade links, transit, transport communications (1920-1930s). Far East Probl. 2010, 5, 72-85.

8. Aristova, L.B.; Semenova, N.K. New transport policy priorities in the format RF-CA-China. Bull. Novosib. State Univ.Ser. Hist. Philol. 2016, 15, 167-176.

9. Wu, L.; Zhang, L.G.; Lai, Y.; Chen, J. Risk assessment of highspeed railway tunnel construction based on fuzzy systhenic evaluation. Adv. Mater. Res. 2012, 594-597, 1251-1256.

10. Dong, S.C.; Yang, Y.; Li, F.J.; Cheng, H.; Li, J.N.; Bilgaev, A.; Li, Z.H.; Li, Y. An evaluation of the economic, social, and ecological risks of China-Mongolia-Russia high-speed railway construction and policy suggestions. J. Geogr. Sci. 2018, 28, 900-918. [CrossRef]

11. Dong, S.C.; Yang, Y.; Li, F.J.; Cheng, H.; Li, J.N.; Bilgaev, A.; Li, Z.H.; Li, Y. Influencing mechanism and policy suggestions of China-Mongolia-Russia high-speed railway construction. Acta Geogr. Sin. 2019, 74, 297-311.

12. Baklanov, P.Y. Geosystems of Far East of Russia on Boundary of XX-XXI Century; Dalnauka: Vladivostok, Russia, 2008.

13. Baklanov, P.Y. Pacific Russia: Pages of Past, Present, and Future; Dalnauka: Vladivostok, Russia, 2012.

14. Sazonov, S.L. The role of transport in development of China. Asia Afr. Today 2015, 1, $20-24$.

15. Sub, B.H. China's one Belt and one Road Initiative and China-Russia Cooperation: Focusing on transportation logistics cooperation in the China's Northeast and the Russia's Far East. Small and Medium Stud. 2019, 42, 293-324.

16. Ding, S.B.; Wang, R.C. Study on trans -boundary corridors and their contributions to regional environment in Tumen River Area. J. Northeast Norm. Univ. 2002, 3, 113-120.

17. Guo, L.C.; Zhou, Y.; Ma, B. Transportation network and spatial economic linkages of urban agglomeration between Northeast China and the Russian Far East. Northeast Asia Forum 2017, 26, 72-83, 128.

18. Liu, Q.C.; Qi, X. On the regional development strategic connectivity and cooperation between Northeast China and the Far East of Russia under the framework of Belt and Road Initiative. Northeast Asia Forum 2018, 2, 34-52.

19. Li, X. Russian's “One Belt and One Road”: Unified Eurasian Conception. Sib. Stud. 2018, 45, 5-12, 93.

20. MOC. Sino Russian Cooperation and Development Plan in the Far East of Russia (2018-2024). Available online: http://www. mofcom.gov.cn/article/guihua/201811/20181102807004.shtml (accessed on 11 February 2020).

21. Chu, N.C.; Zhang, P.Y.; Li, H. High-speed rail impact on regional accessibility and its spatial effects: A case study of the Blagoveshchensk-Vladivostok railway. Prog. Geogr. 2019, 38, 988-997.

22. Jin, F.J.; Chen, Z. Evolution of transportation in China since reform and opening up: Patterns and principles. J. Geogr. Sci. 2019, 29, 1731-1757. [CrossRef] 
23. Niu, F.; Wang, F.; Chen, M. Modelling urban spatial impacts of land-use/ transport policies. J. Geogr. Sci. 2019, $29,197-212$. [CrossRef]

24. Cui, X.; Fang, C.; Wang, Z.; Bao, C. Spatial relationship of high-speed transportation construction and land-use efficiency and its mechanism: Case study of Shandong Peninsula urban agglomeration. J. Geogr. Sci. 2019, 29, 549-562. [CrossRef]

25. Dong, S.C.; Cheng, H.; Guo, P.; Li, F.J.; Li, Y.; Li, Z.H.; Zhang, X.X. Transportation Industry Patterns and Strategy of the Belt and Road. Bull. Chin. Acad. Sci. 2016, 31, 663-670.

26. Yang, C.W.; Li, Z.H.; Guo, X.Y.; Yu, W.Y.; Jin, J.; Zhu, L. Application of BP neural network model in risk evaluation of railway construction. Complexity 2019. [CrossRef]

27. Jin, J.; Li, Z.H.; Zhu, L.; Tong, X.H.; Yang, C.W. Application of BP neural network in risk evaluation of railway construction. J. Railw. Eng. Soc. 2019, 3, 103-109.

28. Liu, G.P.; Chen, L.W.; Zhao, W.Z. Evaluation index system of highway construction project investment risk. Constr. Econ. 2015, 36, 43-46.

29. Benítez-López, A.; Alkemade, R.; Verweij, P.A. The Impacts of Roads and other Infrastructure on mammal and bird population: A meta-analysis. Biol. Conserv. 2010, 143, 1307-1316. [CrossRef]

30. Beyer, H.L.; Ung, R.; Murray, D.L.; Fortin, M.J. Functional Response, Seasonal Variation and Thresholds in Behavioral Response of Moose to Road Density. J. Appl. Ecol. 2013, 50, 286-294. [CrossRef]

31. Kociolek, A.V.; Clevenger, A.P.; St. Clair, C.C.; Proppe, D.S. Effect of Road Network on Bird Population. Conserv. Biol. 2011, 25, 241-249.

32. Wang, Y.Y. The Environmental Issues and Cooperation of Green Development in Building China-Mongolia-Russia Economic Corridor. J. Northeast Asia Stud. 2019, 3, 69-80.

33. Dong, S.C. International Scientific Investigation Supports Green Silk Road Construction. Available online: http://www.rmhb. com.cn/zt/ydyl/201909/t20190903_800177510.html (accessed on 12 November 2020).

34. Zhang, Y. Dong Suocheng: Scientist of the Green Construction of the "B\&R". Bulletin of Chinese Academy of Sciences, 2018-12-08. Available online: https://mp.weixin.qq.com/s/WyXAOk9on-8U97ysiyWNyw (accessed on 12 November 2020).

35. Information Agency Invest Infra of Russia (IAII). The Ministry of Transport of Russia Considered the Cost of Construction and Reconstruction of a Kilometer of Public Roads. Available online: https:/ /investinfra.ru/novosti/mintrans-rossii-poschitalstoimost-stroitelstva-i-rekonstrukcii-kilometra-avtomobilnyh-dorog-obschego-polzovaniya.html (accessed on 21 March 2020).

36. Railway Special Project (RSP). Design, Construction and Repair Railway Company. The Cost of Construction of $1 \mathrm{~km}$ of the Railway in 2019. Available online: https:/ / xn--d1abbab2adzbibjdkw2d.xn--p1ai/stoimost-stroitelstva-1km-zd-puti (accessed on 21 March 2020).

37. Development Concept of Primorsky No. 1 and Primorsky No. 2 International Transport Corridor. Available online: http: / / static.government.ru/media/files/jqfm5N1YLGTTVhUn3AKqOAg9mJcb2Yxx.pdf (accessed on 15 February 2020).

38. Primorsky Statistical Yearbook 2018. Available online: https:/ / primstat.gks.ru/ (accessed on 31 January 2020).

39. European Space Agency: Landcover Climate Change Initiative. Available online: http://maps.elie.ucl.ac.be/CCI/viewer/ download.php (accessed on 2 March 2020).

40. Xiao, J.H.; Yao, Z.Y.; Qu, J.J. Influence of Golmud-Lhasa section of Qinghai-Tibet railway on blown sand transport. Chin. Geogr. Sci. 2015, 25, 39-50. [CrossRef]

41. Zhang, R.S.; Pu, L.J.; Zhu, M. Impacts of transportation arteries on land use patterns in urban rural fringe: A comparative gradient analysis of Qixia district, Nanjing City, China. Chin. Geogr. Sci. 2013, 23, 378-388. [CrossRef]

42. Popp, J.N.; Boyle, S.P. Railway ecology: Underrepresented in science? Basic Appl. Ecol. 2017, 19, 84-93. [CrossRef]

43. Li, F.J.; Liu, Q.; Dong, S.C.; Cheng, H.; Li, Y.; Yang, Y.; Tsydypov, B.; Bilgaev, A.; Ayurzhanaev, A.; Bu, X.Y.; et al. Investment Environment Assessment and Strategic Policy for Subjects of Federation in Russia. Chin. Geogr. Sci. 2019, 29, 887-904. [CrossRef]

44. Dong, S.C.; Zheng, J.; Li, Y.; Li, Z.H.; Li, F.J.; Jin, L.; Yang, Y.; Bilgaev, A. Quantitative Analysis of the Coupling Coordination Degree Between Urbanization and Eco-environment in Mongolia. Chin. Geogr. Sci. 2019, 29, 861-871. [CrossRef]

45. Shi, B.F.; Yang, H.F.; Wang, J.; Zhao, J.X. City Green Economy Evaluation: Empirical Evidence from 15 Sub-Provincial Cities in China. Sustainability 2016, 8, 551. [CrossRef]

46. Shi, Y.F.; Ge, X.H.; Yuan, X.L.; Wang, Q.S.; Kellett, J.; Li, F.Q.; Ba, K.M. An Integrated Indicator System and Evaluation Model for Regional Sustainable Development. Sustainability 2019, 11, 2183. [CrossRef]

47. Lin, W.X.; Hong, C.Q.; Zhou, Y.K. Multi-Scale Evaluation of Suzhou City's Sustainable Development Level Based on the Sustainable Development Goals Framework. Sustainability 2020, 12, 976. [CrossRef]

48. Gorchakov, V.V.; Popov, Y.U. Atlas of Primorsky Krai; PrimorAGP: Vladivostok, Russia, 2008.

49. Adzhiev, A.H.; Bartalev, S.A.; Bekkiev, M.Y. Ecological Atlas of Russia; Feoriya: Moscow, Russia, 2017.

50. Song, S.B.; Cai, H.J.; Xu, L.F. Indicators system for region sustainable water resources utilization and its assessing methods. Adv. Water Sci. 2003, 14, 647-652.

51. Chen, Y.T.; Chen, G.H.; Li, M.J. Classification and research advancement of comprehensive evaluation methods. J. Manag. Sci. China 2004, 7, 69-79.

52. Peng, Z.L.; Zhang, Q.; Yang, S.L. Overview of comprehensive evaluation theory and methodology. Chin. J. Manag. Sci. 2015, 23, 245-256. 
53. Wang, F.X.; Mao, A.H.; Li, H.L.; Jia, M.L. Quality Measurement and Regional Difference of Urbanization in Shandong Province Based on the Entropy Method. Sci. Geogr. Sin. 2013, 33, 1323-1329.

54. Ma, Y.M.; Wu, Y.M.; Wu, B.J. Comprehensive Evaluation of Sustainable Urban Development of Yangtze River Delta Based on Entropy Method and Quadrant Method. Econ. Geogr. 2015, 35, 47-53.

55. Chen, Q.Q.; Zhang, J.B.; Zhang, L. Risk Assessment, Partition and Economic Loss Estimation of Rice Production in China Sustainability 2015, 7, 563-583. [CrossRef]

56. Xiao, Q.; Wan, S.S.; Lu, F.C.; Li, S. Risk Assessment for Engagement in Sharing Economy of Manufacturing Enterprises: A Matter-Element Extension Based Approach. Sustainability 2019, 11, 4774. [CrossRef]

57. Cheng, W.; Yin, H. A study on Russian industrial mix evolution. Russ. East Eur. Cent. Asian Stud. 2009, 1, 37-43.

58. The People's Daily. Russia Has Issued the Free Distribution Act of Russian Far East Land. Available online: http://www. xinhuanet.com/politics/2016-05/04/c_128954095.htm (accessed on 21 March 2020).

59. City Strategy. Strategies for Socio-Economic Development in the Russian Far East and Baikal Region before 2025. 28 December 2009. Available online: http://www.city-strategy.ru/UserFiles/Files/Strategy\%20DVFO_2025.pdf (accessed on 21 March 2020).

60. MOC. Socio-Economic Development Planning in the Far East and Baikal Region of Russia. 4 December 2013. Available online: http:/ / www.mofcom.gov.cn/article/i/dxfw/jlyd/201312/20131200411864.shtml (accessed on 21 March 2020).

61. Ministry for the Development of the Russian Far East. Conception on the Development of Border Areas in the Russian Far East Federal Region and the Baikal Region. Available online: https:/ / minvr.ru/activity/kompleksnoe-razvitie-territoriy/razvitieprigranichnykh-territoriy/\# (accessed on 21 March 2020).

62. Abramov, A.L.; Diaghilev, A.A.; Kuznetsova, G.D.; Melamed, I. Social and Economic Situation and Prospects for the Development of Primorsky Krai for the Period up to 2024 (Part I). Cust. Policy Russia Far East 2018, 2, 25-46. [CrossRef]

63. Vladivostok Free Port Policy. Available online: http://world.people.com.cn/n/2015/0915/c157278-27586965.html (accessed on 21 March 2020). 